\title{
EL PRECEDENTE EN EL DERECHO INGLÉS: UNA VISIÓN DESDE LA CIUDADELA
}

\author{
Simon Whittaker ${ }^{*}$ \\ Traducción de Cristián Banfi del Río** \\ Nota del traductor ${ }^{* * *}$
}

\begin{abstract}
RESUMEN: En este artículo el autor procura explicar, a juristas con una formación distinta que la del Common Law, el enfoque de los tribunales ingleses hacia el efecto revestido de autoridad de las decisiones previas ("precedentes" en un primer sentido), postura que el Derecho inglés ha fijado famosamente (o en forma tristemente célebre) en el marco de la "doctrina del precedente", en cuya virtud los fallos anteriores pueden obligar a tribunales posteriores ("precedente" en un segundo sentido). Para este objeto, el autor en primer lugar ubica esta doctrina en el contexto de ciertas características particulares del sistema jurídico en general (la posición constitucional de los jueces, la relación entre ley y Common Law, la unidad de las instituciones judiciales inglesas y las respectivas funciones de jueces y partes). A continuación, el autor describe la doctrina formal del precedente pero buscando exponer el uso de los precedentes antiguos por parte de los jueces ingleses modernos, lo que ilustra con la reciente sentencia de la Cámara de los
\end{abstract}

* El presente texto es una traducción -con modificaciones acordadas con el autor- del artículo original de Simon Whittaker, "Precedent in English Law: A View from the Citadel" (2006) 5 European Review of Private Law pp. 705-746 (C) Kluwer Law International, Países Bajos. Simon Whittaker es profesor de Derecho Comparado Europeo, Facultad de Derecho, Universidad de Oxford; Fellow y Tutor en Derecho, St. John's College, Oxford. El autor expresa su más sincera gratitud al profesor Banfi por la reflexión y el cuidado puestos en esta traducción. El autor agradece asimismo al profesor Sergio Cámara Lapuente, de la Universidad de La Rioja, España, por sus útiles sugerencias a la presente traducción.

** Licenciado en Derecho, Pontificia Universidad Católica de Chile (1994). Magíster en Derecho Privado, Universidad de Chile (2000); LL.M., Universidad de Cambridge (2002); Profesor de Derecho Civil, Universidad de Chile. El traductor agradece al profesor Whittaker y al profesor Ewoud Hondius, editor de European Review of Private Law, para traducir y publicar este importante artículo en la Revista Chilena de Derecho, así como también el interés de esta última en su difusión. Asimismo agradece, además, al profesor Sergio Cámara Lapuente por sus valiosas observaciones durante la elaboración de este trabajo. El traductor asume la responsabilidad por los errores u omisiones que este texto pueda contener.

*** Los siguientes términos han sido traducidos según se indica a continuación: House of Lords como "Cámara de los Lores"; Lordships como "lores"; tort como "ilícito"; law of tort como "responsabilidad extracontractual"; tort of negligence como "ilícito de negligencia"; equity como "equidad"; privity of contract como "efectivo relativo de los contratos"; undue influence como "influencia indebida"; economic duress como "coacción económica"; conversion como "apropiación ilícita”. En abono de la claridad, se ha preferido conservar en su idioma original correspondiente -esto es, inglés, francés o alemán-, expresiones tales como Lord, Common Law, estoppel, High Court, Privy Council, consideration, LJ (Lord Justice), Conseil d'Etat, Cour de cassation, Code, droit commun, Treu und Glauben, etc. El término consideration se entiende como el requisito establecido por el Derecho inglés para distinguir entre las convenciones consideradas gratuitas (y que, en principio, son inexigibles como contratos) y las de carácter oneroso (y que, por ende, pueden hacerse cumplir como contratos). A lo largo del artículo se emplean las abreviaturas "UE” y "CE" que corresponden a "Unión Europea” y "Comunidad Europea”, respectivamente. En fin, se ha respetado la forma oficial y correcta de citar la jurisprudencia inglesa. 
Lores en Shogun Finance Ltd. v. Hudson. La imagen que emerge es mucho más compleja de lo que la doctrina formal sugiere: los jueces ingleses, en lugar de seguir mecánicamente las resoluciones previas, se comprometen firmemente con la diversidad de posturas, técnicas, principios y consideraciones que descubren en las resoluciones anteriores y evalúan los argumentos sustantivos que estas enfrentan. En todo esto, ellos están dispuestos a innovar aunque conscientes de las limitaciones prácticas y constitucionales que pesan sobre el Derecho de origen judicial. En una sección final del ensayo, el autor considera si los jueces ingleses extienden su tratamiento de los procesos del Common Law a las sentencias dictadas por el Tribunal de Justicia de las Comunidades Europeas o el Tribunal Europeo de Derechos Humanos.

Palabras clave: Doctrina del precedente, jueces ingleses, Common Law, Tribunal de Justicia de las Comunidades Europeas, Tribunal Europeo de los Derechos Humanos.

ABSTRACT: In this paper, the author seeks to explain to lawyers other than from a Common Law background the approach of English courts to the authoritative impact of previous decisions ('precedents' in a first sense), an approach which English law has famously (or notoriously) set in the framework of the 'doctrine of precedent' by which previous decisions can bind subsequent courts ('precedent' in a second sense). In order to do so, the author first sets this doctrine in the context of certain particular features of the wider legal system (the constitutional position of judges, the relationship between statute and the Common Law, the unity of English judicial institutions and the relative roles of judges and the parties). The author then describes the formal doctrine of precedent but then seeks to explain the use of earlier authority by modern English judges, illustrating this by reference to the recent decision of the House of Lords in Shogun Finance Ltd. v Hudson. The picture which emerges is much more complex than the formal doctrine suggests: rather than following previous decisions in a mechanistic way, English judges engage closely with the variety of approaches, techniques, principles and considerations which they find in earlier judgments, and they evaluate the substantive arguments which these address. In all this, they are willing to innovate, though they are also conscious of the practical and constitutional limitations on judicial law-making. In a final part of the paper, the author considers whether English judges extend their treatment of Common Law cases to decisions of the European Court of Justice or the European Court of Human Rights.

Key words: Doctrine of precedent, english judges, Common Law, European Court of Justice, European Court of Human Rights.

"Aunque la adhesión al precedente ha sido ridiculizada por algunos, por lo menos desde el tiempo de Bentham, como una fórmula para la perpetuación del error, este ha constituido una piedra angular de nuestro sistema jurídico" (Lord Bingham de Cornhill, 2006) ${ }^{1}$.

"En verdad, los jueces hacen y cambian el Derecho. La totalidad del Common Law es creación del juez y solo mediante la modificación judicial en el Derecho, el Common Law conserva su vigencia en un mundo cambiante" (Lord Browne-Wilkinson, 1999)².

\footnotetext{
${ }^{1}$ Leeds City Council v. Price (2006) UKHL 10 párr. 42 (Transcripción Lexis). Una de las críticas más mordaces de Jeremy Bentham acerca del carácter tolerante de la tradición del Common Law hacia el error se aprecia en su obra A Fragment on Government (1776) (disponible en extenso en: http://www.yale.edu/lawweb/avalon/ avalon.htm), la cual censuró los Commentaries on the Law of England de Sir William Blackstone.

${ }^{2}$ Kleinwort Benson Ltd. v. Lincoln City Council (1999) 2 AC 349, p. 358.
} 
En las mentes de muchos estudiantes y eruditos del Derecho comparado y la teoría jurídica, se observa que el Derecho inglés ocupa un lugar especial en toda descripción del rol que los jueces desempeñan en el desarrollo o la creación jurídica ${ }^{3}$. En efecto, durante varios siglos el Derecho inglés ha situado a los jueces a la vanguardia de su razonamiento jurídico, considerándolos, en las famosas palabras de Sir William Blackstone, como los "oráculos vivientes" del Derechó ${ }^{4}$ Porque ¿no es el Common Law -más que la legislación- el punto de partida del Derecho inglés? ¿Y quién, si no son los jueces, ha de declarar con autoridad el contenido del mismo? Más aún, en determinadas ocasiones los jueces han desempeñado un papel muy importante en la evolución constitucional de Inglaterra: primero, afirmando la sujeción de los actos independientes de la Corona (prerrogativa real) al Common Law (como han declarado los tribunales) desde comienzos del siglo diecisiete ${ }^{5}$; y segundo, en el desarrollo de la revisión judicial de los actos administrativos a partir de $1960^{6}$. Asimismo, la trascendencia y autoridad tradicionales otorgados a los casos fallados ("precedentes" en el amplio sentido identificado por John Bell) ${ }^{7}$ por los juristas ingleses (y, notablemente, jueces posteriores) fueron reforzadas durante el siglo XIX mediante un conjunto de normas en cuya virtud una sentencia anterior (o, al menos, parte de la misma, su ratio decidendi) fue declarada formal y jurídicamente vinculante para un tribunal posterior. Este conjunto de reglas devino conocido como la doctrina del precedente $\mathrm{u}$ ocasionalmente stare decisis (precedente en el segundo sentido señalado por John Bell $)^{8}$. Para un forastero, este segundo aspecto del tratamiento inglés del proceso de elaboración de decisiones judiciales previas resulta muy peculiar y, a veces al menos, muy desconcertante. Esto, porque la doctrina del precedente contiene una paradoja central, ya que si bien reconoce la legitimidad del Derecho de creación judicial (lo que un juez hace puede obligar a otros jueces posteriores), al mismo tiempo la constriñe dentro de márgenes bastante estrictos. Además, tan pronto uno mira allende las descripciones del esbozo de la doctrina del precedente y estudia cualquier área del Derecho inglés sustantivo, queda claro que el tratamiento judicial inglés de los litigios previos es del todo menos restringido, más audaz y mucho más sutil que lo que insinuarían las reglas formales del precedente. Adicionalmente, parecieran existir diferencias considerables en el grado de osadía de los jueces ingleses según el período

\footnotetext{
${ }^{3}$ Vg. MacCormick y Summers (1997) cap. 1, en relación al Common Law en general, aunque cuidan de matizar la aparente escisión entre el Common Law y el Derecho Civil. A lo largo de este trabajo me referiré al Derecho "inglés", que es el término clásico utilizado para describir el Derecho de Inglaterra y Gales. No comentaré el Derecho de Escocia ni el de otras zonas del Reino Unido, en donde el Derecho inglés no rige.

${ }^{4}$ BLACKSTONE (1765-1769) p. 69. Esta denominación fue empleada por John. P. Dawson en su gran obra histórica y comparada que trata del rol de los jueces, The Oracles of the Law: DAWSON (1968).

5 The Case of Proclamations (1610) 12 Co Rep 74, p. 76 ("El Rey no tiene prerrogativa, excepto aquella que el Derecho de la tierra le concede").

${ }^{6}$ WADE y FORSYTH (2004) pp. 17-19.

7 BELL (2000) pp. 28-29.

${ }^{8}$ BELL (2000) p. 29.
} 
histórico ${ }^{9}$, el ámbito sustantivo del Derecho ${ }^{10}$, e incluso de la predilección de los propios jueces. Sobre el particular, por supuesto no puedo dejar de mencionar las diversas innovaciones introducidas por Lord Denning, ya fallecido (algunas de las cuales perviven ${ }^{11}$ y otras han sido erradicadas completamente ${ }^{12}$ ), cuya reputación obedece en parte a la extensión de su creación y en parte al estilo meridianamente claro de sus sentencias. Aun cuando la contribución de Lord Denning puede considerarse excepcional (para bien o para mal), todavía es un hecho que algunos jueces superiores son más proclives a emprender una generalización o creatividad de mayor alcance que otros. De este modo, en cierto sentido la interpretación de la doctrina del precedente y su aplicación práctica constituyen una expresión de la individualidad y personalidad judiciales. Quizá sorprendentemente, atendido el valor asignado a la certeza jurídica consagrada por la doctrina del precedente, esta individualidad no es generalmente objeto de crítica por los juristas ingleses en forma más amplia, salvo, tal vez, cuando diversas posturas respecto del mismo asunto tornan imposible la interpretación acerca de su impacto real ${ }^{13}$.

Claramente, entonces, en el contexto inglés, el papel de las decisiones anteriores en la aplicación y/o en el desarrollo del Derecho es un tema vasto, sobre el cual se ha escrito profusamente (no menos desde el punto de vista de la teoría general del Derecho o, al menos, de la teoría del Common $\left.L a w^{14}\right)$. En el presente ensayo no puedo embarcarme en una discusión de estos debates más teóricos, sino que en su lugar pretendo realizar cuatro tareas.

En primer término, ofreceré algún indicio de la posición de los jueces en el ámbito constitucional, institucional y procesal más amplio del sistema jurídico inglés y sugeriré la forma en que este entorno se vincula al empleo del precedente ${ }^{15}$. En segundo término, expondré las reglas formales del precedente conforme los tribunales ingleses las reconocen en la actualidad ${ }^{16}$. En tercer término, intentaré proveer algún significado de las formas en que los precedentes son efectivamente utilizados por los tribunales, me-

\footnotetext{
${ }^{9}$ Se ha indicado, por ejemplo, que los jueces ingleses fueron particularmente conservadores en su aproximación al Derecho administrativo durante el siglo veinte hasta los años sesenta, porque esta área "recayó en un estado impotente marcado por el descuido de los principios y una interpretación verbal literal de los cheques en blanco con que el Parlamento colmó a los Ministros": WADE y FORSYTH (2004) p. 16.

${ }^{10}$ Por ejemplo, los tribunales ingleses en general han sido mucho menos propensos a modificar el Derecho de los contratos que el de la responsabilidad civil extracontractual.

${ }^{11} \mathrm{Vg}$. la extensión del principio ("en equidad") del estoppel a la obligación de aceptar una suma menor como pago total de una deuda: Central London Property Trust Ltd. v. High Trees House Ltd. (1947) KB 130; D\& C Builders v. Rees (1965) 3 All ER 837.

12 Vg. el "error en equidad" usado por Lord Denning en Solle v. Butcher (1950) 1 KB 671, pero que con posterioridad la Corte de Apelaciones estimó en Great Peace Shipping Ltd. v. Tsavliris Salvage (International) Ltd. (2002) EWCA Civ 1407; (2003) QB 679, que contradecía la sentencia de la Cámara de los Lores en Bell v. Lever Bros (1932) AC 161. Un ejemplo ulterior puede descubrirse en la doctrina del "incumplimiento fundamental" referida infra 3.4, p. 32, circa n. 182.

13 Véase, vg., Shogun Finance Ltd. v. Hudson (2003) UKHL 62; (2004) 1 AC 919, infra 3.1, pp. 18-24, circa n. 89 a n.122.

${ }^{14}$ Las contribuciones más insignes pertenecen a HART (1961) cap. 7; y DWORKIN (1977) cap. 4 ("Casos Díficiles"). Para una introducción general de la doctrina del precedente, véase Cross y HARRIS (1990).

${ }^{15}$ Infra 1 , pp. 5-13.

${ }^{16}$ Infra 2, pp. 13-18.
} 
diante algunas ilustraciones de jurisprudencia reciente, extraídas en particular del Derecho de los contratos y de la responsabilidad extracontractual ${ }^{17}$. En cuarto término, consideraré muy sucintamente el tratamiento otorgado por los jueces ingleses a la jurisprudencia que emana del Tribunal de Justicia de las Comunidades Europeas (“TJCE”) y del Tribunal Europeo de Derechos Humanos (“TEDH”)18. En todo esto, trataré de describir los rasgos de singular interés desde una perspectiva de Derecho comparado.

\section{LA POSICIÓN DE LOS JUECES EN EL SISTEMA JURÍDICO INGLÉS}

En mi opinión, tres son las características fundamentales de la posición de los jueces ingleses: (i) su relación con el Parlamento, la que refleja -en parte- la vinculación entre el Common Law y la ley; (ii) los acuerdos institucionales modernos implementados para el ejercicio de la función jurisdiccional; y (iii) las funciones respectivas de los jueces y de las partes en la conducción y resolución de un pleito.

\subsection{COMMON LAW Y LEY; LOS JUECES Y EL PARLAMENTO}

Mirado desde el ángulo de varios otros sistemas jurídicos europeos, el aspecto más notable del Derecho inglés todavía es la ausencia de Derecho codificado y, en especial, de Código Civil ${ }^{19}$. Para un iusprivatista continental, es axiomático que el punto de partida para el análisis de un problema jurídico siempre estará constituido por las normas del Código Civil, aun si son interpretadas ampliamente por la doctrina o aplicadas creativamente por los tribunales. Incluso, si una cuestión específica no está reglamentada directamente por el Código Civil (o por otra legislación, ya sea codificada ${ }^{20}$ o "especial"21), el Código establece la forma en que el asunto debe ser resuelto, proporcionando (expresa o tácitamente) los principios jurídicos orientadores y un conjunto de instrumentos jurídico-conceptuales. Es más, el Código hace esto de una manera que apunta a la coherencia jurídica adjetiva y sustantiva, vale decir, no solo a la consistencia en el manejo de materias similares, sino también a la relación entre temas parecidos y la distinción de otros. Esto significa que, aunque un jurista civilista pueda no tomar muy en serio su Código Civil ${ }^{22}$, este aún domina el pensamiento jurídico, formando dentro

${ }^{17}$ Infra 3, pp. 18-35.

18 Infra 4 , pp. 35-40.

19 Una reciente y supuesta excepción puede verse en las Normas Procesales Civiles de 1998, las que se autodenominan "un nuevo código procesal cuyo objeto primordial es permitir al tribunal tratar los casos en forma imparcial” (regla 1.1. (1)).

20 Así, por ejemplo, en el Derecho francés las normas que regulan los contratos en general (le droit commun contractuel) pueden ser restringidas o complementadas mediante reglas especiales que gobiernan los contratos comerciales en el Code du commerce o que reglamentan los contratos de consumo en el Code de la consommation.

21 Así, por ejemplo, en el Derecho francés la norma general que regula la responsabilidad por el "hecho de una cosa” está contemplada en el Art. 1384 inc. $1^{\circ}$ del Code (el cual, por casi un siglo, ha sido interpretado muy creativamente por los autores y los tribunales), pero este precepto es corregido y complementado por normas especiales contenidas en la ley $\mathrm{N}^{\circ}$ 85-677, de 5 de julio de 1985, aplicada a situaciones en que vehículos motorizados están involucrados en la producción del daño, reglas que permanecen fuera del Code.

22 LAWSON (1953) p. 56, confirmado en TUNC (1986). 
de su esfera la fuente primaria del Derecho. El trabajo de los eruditos y de los tribunales puede explicar, reinterpretar o, de hecho, reinventar las normas de un Código (como ha sucedido con los célebres juicios sobre "la responsabilité du fait des choses" en Francia) ${ }^{23}$ o el principio de la buena fe (Treu und Glauben) en Alemania ${ }^{24}$, pero estas otras fuentes jurídicas ${ }^{25}$ son en realidad secundarias, conformando estratos -aun si son capas inmensamente significativas- alrededor de la propia legislación.

Por el contrario, el punto de partida del Derecho inglés continúa siendo el Common Law. Aquí nuevamente hallamos una paradoja. En efecto, los jueces ingleses desde antiguo aceptan que, cuando tiene aplicación, una ley del Parlamento posee la virtud de modificar o incluso sustituir el Common Law, lo que en términos constitucionales es visto como resultado del principio de la soberanía parlamentaria ${ }^{26}$. Sin embargo, si el Derecho legislado emanado del Parlamento es la fuente jurídica (nacional) suprema ${ }^{27}$, el Common Law lo precede pues configura el cuerpo normativo que reglamenta un conjunto de hechos en defecto de cualquier otro: tomando prestada la terminología francesa y a riesgo de caer en un juego de palabras engañoso, el Common Law constituye el droit commun. ${ }^{28}$ Esto acarrea varias consecuencias de la mayor importancia para la comprensión de la relación entre el Common Law y la ley.

En primer lugar, la legislación parlamentaria ${ }^{29}$ todavía es considerada excepcional o, como finamente indicara el extinto profesor Nicholas, las leyes constituyen "irrupciones aisladas" en el grueso del Common Law ${ }^{30}$. Desde luego, esto no implica negar la

${ }^{23}$ Art. 1184 inc. $1^{\circ}$ del Code. Véase al respecto: LAWSON y MARKESINIS (1982) pp. 97-99.

$24 \$ 242$ BGB. Véase al respecto (en inglés): WhitTAKer y ZimmermanN (2000) pp. 18-31.

${ }^{25}$ Evidentemente, en algunas jurisdicciones se discute si la doctrina o la jurisprudencia pueden ser consideradas propiamente como "fuentes" del Derecho. La postura tradicional en Francia ha sido negar a la jurisprudencia el rótulo de "fuente" jurídica, aunque simultáneamente confirmar su relevancia práctica: vg. CARBOnNier (1990) p. 247 ("La jurisprudence n'est pas une véritable source du droit civil”); Bell et al. (1998) pp. 25-38.

${ }^{26}$ Aquí, incluso, esta afirmación debe ser matizada, especialmente sobre la relación entre diversos intentos del legislador por derogar o de otro modo evitar la revisión judicial del acto administrativo: véase CRAIG (2003) Cap. 24.

${ }^{27}$ Más polémico es sostener que la ley es la fuente jurídica suprema en el Reino Unido, dado su carácter de miembro de la UE. En efecto, aunque los tribunales ingleses han aceptado el principio de la supremacía del Derecho de la UE (véase infra 4.1, pp. 35-36), este en la práctica puede ser conciliado a nivel formal con el principio de la soberanía del Parlamento del Reino Unido, indicándose la Ley sobre las Comunidades Europeas de 1972 como el soporte legal del Derecho de la UE en el Reino Unido. El estatus jurídico del Convenio Europeo sobre Derechos Humanos en el Derecho nacional del Reino Unido es más complejo: véase infra 4.2, pp. 38-41.

${ }^{28} \mathrm{El}$ juego de palabras puede no ser totalmente impertinente, ya que el uso original de la terminología del "common" law tuvo un significado muy similar a la noción francesa le droit commun. En efecto, los juristas ingleses emplearon el Common Law en la época de Eduardo I para describir el Derecho en general, cotejado con "lo que sea particular, extraordinario, especial", tal como una ley, una prerrogativa real o una costumbre local: POLLOCK y MAITLAND (1968) p. 177, con una introducción de S.F.C. Milsom.

${ }^{29}$ La Corona no puede modificar el Common Law por sí sola: The Prince's Case (1606) 8 Co Rep 13 b, 19b. Por otra parte, el Common Law efectivamente reconoció que las companías constituidas por la Corona podían dictar leyes de inferior jerarquía ("estatutos") para el fomento de sus objetivos, incluso para quienes no eran socios en las mismas. Véase WhitTaKer (2001) pp. 108-116.

${ }^{30}$ NiCHOLAS (1989) pp. 166 y 178. 
enorme importancia de las leyes modernas ni que estas ocasionalmente dominan un área sustantiva del Derecho en particular (como, por ejemplo, en el Derecho societario o inmobiliario). Pero, incluso, cuando el Parlamento ha participado, sus intervenciones a menudo (aunque no siempre ${ }^{31}$ ) han afectado un campo ya regulado por el Common Law; y si bien la ley a veces deroga el Common $L a w^{32}$, con bastante frecuencia simplemente lo complementa ${ }^{33}$ o rectifica uno de sus atributos ${ }^{34}$. De este modo, el legislador usualmente recurre a conceptos que en sí mismos solo pueden entenderse con referencia al Common Law. Así, al consagrar una acción por daños derivados del dolo que induce a contratar, la ley sobre falsa representación del año 1967 se fundó en el Common Law, al menos en dos aspectos: primero, mediante el empleo de las palabras "falsa representación” en una forma que manifiesta su adopción de la definición de este término de arte existente en el Common Law; y, segundo, al valerse de la que se conoce como "ficción del fraude”, explicitó que la responsabilidad que este desencadenaba debía ser clasificada como extracontractual ${ }^{35}$. Evidentemente, en otras oportunidades una de las razones principales de la intervención legislativa ha sido la necesidad de introducir conceptos o principios nuevos que no se encuentran en el Common Law: esto puede apreciarse con particular claridad en la legislación de la década de 1970, la que incorporó normas que protegen abiertamente a los "consumidores", una noción que las mismas leyes fueron cuidadosas de definir (distinguiendo según los diversos objetivos de la legislación pertinente $)^{36}$. Sin embargo, la naturaleza "excepcional" y en cierto sentido secundaria de las leyes inglesas, efectivamente influye en la creatividad judicial. Primero, los jueces ingle-

31 Ejemplos de elaboración de normas en una área no legislada o regulada por el Common Law pueden hallarse en la regulación de los mercados, tal como los antiguos servicios públicos o los servicios financieros.

${ }^{32} \mathrm{Vg}$. Ley sobre Responsabilidad de los Ocupantes de 1957, art. 1: "Las normas establecidas en los dos artículos siguientes tendrán efecto, en lugar de las normas del Common Law...”.

33 Vg. Ley sobre Protección del Consumidor de 1987, Parte I (dando efecto en el Reino Unido a la Directiva 85/374/CEE sobre responsabilidad por los daños causados por productos defectuosos), la que complementa las acciones del Common Law por el ilícito de negligencia y la responsabilidad por incumplimiento contractual. Cf. Ley sobre Locales Defectuosos de 1972, art. 1 (añadiendo un nuevo recurso respecto de la construcción de viviendas), la que complementa la acción fundada en el incumplimiento contractual o en el ilícito de negligencia. Empero, la promulgación de la ley de 1972 llevó a la Cámara de los Lores a restringir el desarrollo del ilícito de negligencia en esta materia: infra 3.4, p. 33, circa n. 188.

34 Vg. Ley sobre Falsa Representación de 1967, art. 1, que derogó dos limitaciones ("barreras”) que el Common Law contenía en materia de rescisión por dolo que induce a contratar.

35 Ley sobre Falsa Representación de 1967, art. 2(1):

"Cuando una persona ha celebrado un contrato luego de una falsa representación provocada por la otra parte y a consecuencia de ello sufre perjuicio, entonces, si la persona que incurrió en la falsa representación debiese responder por los daños respectivos si la hubiese causado fraudulentamente, responderá igualmente aunque la falsa representación no haya sido provocada en forma fraudulenta, a menos que pruebe que tenía un motivo razonable para creer, y que efectivamente creyó, a la época de la celebración del contrato, en la efectividad de los hechos representados".

La "ficción del fraude" está contenida en las letras cursivas. El carácter de ilicitud extracontractual de los daños fue aceptada por la Corte de Apelaciones en Royscott Trust Ltd. v. Rogerson (1991) 2 QB 297.

${ }^{36} \mathrm{Al}$ respecto, el contraste principal existe entre la Ley sobre Consumidores de Crédito de 1974, art. 8(2) (que define el "contrato de consumo de crédito" como un "contrato de crédito individual" cuyo monto no excede veinticinco mil libras esterlinas) y la Ley sobre Cláusulas Contractuales Abusivas de 1977, art. 12 ("negociando como consumidor"). 
ses generalmente han rehuido elaborar principios más amplios a partir de los ejemplos que las leyes suministran (uno no generaliza basándose en excepciones ${ }^{37}$ ), excepto en diversas situaciones donde se descubren ilustraciones en el Common Law ${ }^{38}$; y, segundo, el Common Law tiene el hábito de crecer a través de las grietas incluso de un esquema normativo aparentemente total, complementándolo si los tribunales lo consideran insuficiente y corrigiéndolo (pero un tanto sotto voce) si de otra manera produciría una injusticia ${ }^{39}$.

En segundo lugar, por cierto, el punto de partida con el Common Law significa que la naturaleza del material sobre el que se construyen muchas decisiones judiciales inglesas difiere radicalmente de aquellos sistemas jurídicos cuya base es legislativa. En efecto, el lugar de inicio no se halla en un texto único -cualquiera sea su extensión o vaguedad- sino que en diversos textos, esto es, en una recopilación de sentencias que abarcan un período que con frecuencia se remonta dos siglos atrás y a veces más. Asimismo, la clase de texto de una sentencia inglesa desde luego se distingue fundamentalmente de todo texto legislativo, siendo aquel por lo regular discursivo o argumentativo, en el cual el juez o los jueces sopesan las consideraciones en pugna identificadas en los casos previos para alcanzar su decisión. Incluso, si un juez busca exponer el Derecho en una o varias proposiciones, estas palabras, por sí solas, carecen de toda fuerza, salvo (inter alia) en su respectivo contexto jurídico y fáctico ${ }^{40}$. Esto reafirma la idea de que las resoluciones anteriores no son simples toques en un cuadro puntillista más amplio (a pesar de que un jurista inglés siempre debe retroceder para apreciar una área del Derecho), porque los textos de las sentencias intentan explicar por sí mismos su relación con lo que ha ocurrido antes y, en algunas oportunidades, con lo que puede suceder con posterioridad. Ciertamente, muchos más fallos recientes ("discursos") de los miembros de la Cámara de los Lores buscan delinear el modelo de las proposiciones jurídicas que atañe al tipo de asunto sometido a su conocimiento, confiriendo sentido a las diversas decisiones anteriores ${ }^{41}$. En una rama del Derecho donde la ley no predomina, los precedentes en los que cualquier tribunal futuro sustentará su

\footnotetext{
${ }^{37}$ NiCHOLAS (1989) p. 190.

${ }^{38}$ Infra 3.2, pp. 25-27, circa n. 129 a n. 147.

39 Esto puede percibirse, en particular, en la manera en que el fideicomiso "implícito" y el "estoppel de propiedad" han sido autorizados para eludir las normas del Derecho inmobiliario, especialmente aquellas sobre la solemnidad de la transacción: véanse, en particular, Hodgson v. Marks (1971) Ch. 89; Yaxley v. Gotts (2000) Ch. 162.

${ }^{40}$ El ejemplo clásico de una forma de palabras que a primera vista pareciera ser tratada como si poseyese toda la fuerza excepto la legislativa, es el pasaje en Rylands v. Fletcher (1865-1866) L.R. 1 Ex. 265, p. 279, confirmado en (1868) LR 3 HL 330, pp. 338-339, pero sus diversos elementos han sido interpretados de un modo que reduce mucho de la fuerza de las palabras tal como estas son realmente expuestas: véanse especialmente Cambridge Water Co. v. Eastern Counties Leather plc (1994) 2 AC 264, pp. 297-300; Transco plc v. Stockport MBC (2003) UKHL 61 (2004), 2 AC 1.

${ }_{41}$ Ejemplos adecuados pueden apreciarse en Royal Bank of Scotland v. Etridge (No 2) (2001) UKHL 44 (2002), 2 AC 773 en relación a las normas sobre influencia indebida en el contrato (aunque los lores discreparon sutilmente en sus puntos de vista) y en el discurso de Lord Hoffmann en Investors Compensation Scheme Ltd. v. West Bromwich Building Society (1998) 1 WLR 896, p. 912, sobre los principios para la interpretación de los contratos.
} 
fallo (y/o que tendrá que distinguir) se mantendrán o caerán por sí solos prescindiendo totalmente de un texto legislativo.

En tercer lugar, aun cuando la presencia del Common Law (elaborado por los tribunales desde los albores de la Edad Media) legitima el rol de los jueces en el desarrollo jurídico, ella también pone de relieve la delicada línea que los jueces ingleses deben evitar traspasar para no inmiscuirse en el dominio del Parlamento. En el ambiente moderno, esta es una frontera que a los jueces ingleses entusiasma observar (y ser vistos que la respetan) por diversos motivos: quieren prevenir que se les acuse de usurpar la función de un legislador democráticamente elegido; quieren evitar pronunciar sentencias que requieran la evaluación de elementos respecto de los cuales son inexpertos o están relativamente desinformados (en especial consideraciones de política social o económica); y quieren eludir tomar decisiones que, aunque puedan parecer generales en los términos en que son expresadas, arriesgan sembrar incertidumbre debido a su fragilidad en manos de tribunales posteriores ${ }^{42}$. Porque si las decisiones inglesas obligan, ello sucede solo en la medida en que un tribunal en el futuro así lo declare. Por tanto, el grado de autocontrol que podemos percibir que los jueces ingleses ejercen en el desarrollo del Derecho, puede ser explicado por su sentido de lo que es apropiado constitucionalmente, la factibilidad de construir normas adecuadas de suficiente aliento y fortaleza en el área de Derecho pertinente, la necesidad de certeza jurídica y la naturaleza apremiante de "justicia" en el caso concreto. Así, si bien a veces encontramos jueces ingleses que aceptan formas de razonamiento radicalmente nuevas, en verdad, nuevos principios jurídicos, a menudo también descubrimos que rehúsan admitirlas con la digresión de que esta materia debiera ser resuelta por el Parlamento ${ }^{43}$.

\subsection{INSTITUCIONES JUDICIALES}

Evidentemente, no es un accidente que la formalización de la doctrina del precedente en el Derecho inglés sucediera en la misma época de la reforma fundamental del sistema de tribunales, de las instituciones judiciales y de los procedimientos civil y penal en general, esto es, en la segunda mitad del siglo XIX, tiempo en el que, además, la publicación de las sentencias fue sistematizada ${ }^{44}$. De este modo, en este período se creó un tribunal uniforme de competencia general (la High Court of Justice, aunque -en cierta medida- los tribunales históricamente distintos fueron perpetuados en las nuevas "divisiones" de dicha corte ${ }^{45}$ ) en lugar de las diversas jurisdicciones que, según puede observarse, habían perdurado en el siglo XIX, como por ejemplo los tribunales del Common Law y de "Equidad" (Chancery) ${ }^{46}$. Simultáneamente, se estableció una nueva

42 Cf. infra 3.3, pp. 30-32, circa n. 169 a n. 177, respecto del principio del efecto relativo de los contratos.

43 Infra 3.3, p. 30, circa n. 170.

${ }^{44}$ CROSS y HARRIS (1990) pp. 24-25.

45 Originalmente estas fueron cinco, denominadas Queen' Bench Division, Chancery Division, Common Pleas Division, Exchequer Division y Divorce and Admiralty Division: Ley sobre Judicatura de la Corte Suprema de 1873, arts. 3-5.

46 En el nivel inferior de la High Court, los tribunales locales de menor cuantía y los Tribunales de Condado poseen una competencia amplia aunque limitada en asuntos civiles. 
Corte de Apelaciones (también una institución unitaria, pero con secciones especializadas en lo civil y penal) ${ }^{47}$ y se confirmó el Comité Judicial de la Cámara de los Lores como un auténtico órgano judicial de última instancia ${ }^{48}$. No obstante que diversos tribunales especiales han surgido con posterioridad (por ejemplo, en el ámbito de las relaciones industriales ${ }^{49}$ y que jueces especializados o procedimientos particulares han madurado al interior de esta estructura (vg., el Tribunal Comercial y el Tribunal Administrativo dentro de la Queen's Bench Division de la High Court), sorprendentemente el sistema judicial inglés permanece unificado. Aunque el aspecto penal mantiene su carácter distintivo y más bien separado, con procesos ante los Magistrates Court y la Crown Court, la apelación es conocida por la Corte de Apelaciones (División Penal) y luego por la Cámara de los Lores. No se observa, por cierto, la suerte de separación jurisdiccional que tan célebremente se aplica en Francia entre los juicios de Derecho público y de Derecho privado, los cuales son fallados, en último término, por el Conseil d'Etat y la Cour de cassation, respectivamente ${ }^{50}$. La postura unitaria inglesa va todavía más lejos, pues el comité judicial de la Cámara de los Lores (cuyo nombre pronto será reemplazado por el de "Corte Suprema") 51 también sirve como el árbitro de mayor jerarquía (a nivel nacional) en todo asunto constitucional. Tradicionalmente esta fue la situación, pues el Derecho constitucional inglés está formado por el Common Law y las leyes, más que por una sola ley específicamente "constitucional" que creaba su propio foro constitucional, pero que fue sucedido por la Ley sobre Derechos Humanos de 1998 (en cuya virtud la Cámara de los Lores permanece como el órgano judicial supremo en la interpretación de los "derechos en el Convenio") ${ }^{52}$ y por las Leyes del Parlamento del Reino Unido que establecieron el Parlamento escocés y la Asamblea Nacional de Gales (donde los mismos jueces que integran la Cámara de los Lores actúan como Privy Council para resolver los "juicios transferidos")53. Todo esto importa la existencia de una notable unidad de personal y criterio en el poder judicial que decide materias del Derecho inglés o relacionadas con él, de manera que aunque existe un cuerpo característico de jurisprudencia sobre Derechos humanos, Derecho administrativo o Derecho constitucional, estos no se hallan divorciados institucionalmente de la jurisprudencia inglesa más general. En cambio, cabe sostener que, por ejemplo, los juristas franceses pueden dar un trato diferen-

\footnotetext{
${ }^{47}$ Ley sobre Judicatura de la Corte Suprema de 1873, arts. 4 y 6. La Corte de Apelaciones en lo Penal solo fue instituida en 1907: Ley sobre Corte de Apelaciones en lo Penal de 1907.

48 Aunque la jurisdicción de la Cámara de los Lores es antigua, los requisitos para la apelación fueron establecidos por la Ley sobre Jurisdicción de Apelación de 1876. Desde entonces únicamente jueces ("Lores de Apelación en lo Ordinario") han conocido de apelaciones.

${ }^{49}$ Tribunal Laboral; Tribunal de Apelación Laboral.

50 Sobre el particular, véase BELL (2001) Cap. 2.

${ }^{51}$ Ley sobre Reforma Constitucional de 2005, Parte III.

52 Cf. infra 4.2, pp. 39-41, circa n. 213 a n. 221.

53 Ley sobre Escocia de 1998, art. 98, anexo 6; Ley sobre Gobierno de Gales de 1998, art. 109, anexo 8; similarmente, Ley sobre Irlanda del Norte de 1998, art. 79, anexo 10. Técnicamente, los jueces concurren como miembros del Comité Judicial del Privy Council, establecido por la Ley sobre Comité Judicial de 1833. Una vez que entre en vigencia la Ley sobre Reforma Constitucional de 2005, los "casos de delegación" serán resueltos por la nueva Corte Suprema del Reino Unido.
} 
ciado a la jurisprudencia de la Cour de cassation, del Conseil d'Etat o del Conseil constitutionnel; de hecho, es común que los juristas que componen cada uno de estos sean distintas personas ${ }^{54}$.

\subsection{LOS ROLES RESPECTIVOS DE LAS PARTES Y DEL TRIBUNAL}

Como he señalado, la fuerza obligatoria del precedente está inextricablemente conectada con los problemas jurídicos enfrentados por el tribunal que debe resolver y con su relación con los hechos de la causa. En mi opinión, existe aquí un importante vínculo entre la naturaleza del proceso judicial, por un lado, y la naturaleza y el tratamiento del precedente inglés, por el otro. La concepción tradicional del proceso civil inglés combina las ideas del carácter contradictorio de las partes y de la pasividad relativa del juez ${ }^{55}$. Una de las consecuencias de esto es que son las partes quienes, mediante sus alegaciones, deben definir los problemas fácticos y jurídicos que disputan y que el tribunal tiene que dirimir ${ }^{56}$ : ellas no solo deben presentar los hechos que dieron origen a la controversia y la calificación jurídica que quieren atribuirles, sino también las voces jurídicas autorizadas (legales o jurisprudenciales) que, desde su perspectiva, justifican esta caracterización y el remedio que procuran obtener ${ }^{57}$. Toca al tribunal decidir si los hechos, tal cual han sido alegados, se encuentran acreditados y si las proposiciones jurídicas, según han sido argüidas, son correctas y conducen a acoger la acción. Las partes no someten meramente una disputa fáctica a la que el tribunal después aplica las consecuencias pertinentes: en este sentido, el Derecho inglés no admite un principio como el que se identifica en Europa continental bajo el adagio curia novit legem.

Esto es significativo para la evolución judicial del Derecho, en las siguientes formas.

En primer término, a nivel formal, ello explica la excepción que se hace a la doctrina de la naturaleza vinculante del precedente cuando un caso anterior fue decidido per incuriam, esto es, con error o ignorancia acerca del estado del Derecho ${ }^{58}$. En efecto, esta excepción reconoce que una decisión previa se refiere a las cuestiones de hecho y de Derecho en discusión y alegadas ante el tribunal; por ende, si las partes no han invocado

\footnotetext{
${ }^{54}$ BeLL (2000) pp. 34-48.

55 En Jones v. National Coal Board (1957) 2 WLR 760, p. 766 Denning LJ señaló:

“(e)n el sistema de juicios que hemos desarrollado en este país, el juez concurre a oír y resolver las cuestiones promovidas por las partes, y no a dirigir una investigación o examen en representación de la sociedad en general, como sucede, creemos, en algunos otros países. Sin embargo, incluso en Inglaterra el juez no es un simple árbitro que responde la pregunta “¿Cómo ocurrió eso?”. Su misión es, sobre todo, encontrar la verdad y hacer justicia de acuerdo al Derecho; y en su búsqueda diaria, el jurista desempeña un rol honorable y necesario. ¿No fue Lord Eldon L.C. quien dijo, en un pasaje notable, que "la verdad mejor se descubre por medio de afirmaciones convincentes a ambos lados de la cuestión'?”.

Para una discusión ulterior sobre las implicancias de esta distribución de funciones, véase WHITTAKER (2005) pp. 205-214.

56 HOLDSWORTH (1926) pp. 264 y 328.

57 Esta separación de roles no ha sido alterada por los cambios conceptuales hacia un "estilo más gerencial”, introducidos por las Normas Procesales Civiles, aunque estas reglas incentivan a los tribunales a reducir los asuntos en disputa entre las partes: véase WHITTAKER (2005) pp. 206-207.

58 Cross y HARRIS (1990) pp. 148-152.
} 
las autoridades pertinentes, la fuerza del fallo es socavada. Cuando un tribunal no "conoce" el Derecho, puede decidir desde la ignorancia.

En segundo lugar, existe una versión más sutil del mismo fenómeno. Porque, incluso si un asunto fue planteado ante un tribunal anterior, pudo no haber sido alegado en su totalidad, y así no devenir relevante en la sentencia del tribunal, la que pretende (en parte) hacer justicia tanto al argumento sostenido por los abogados como a las partes. En realidad, en cierto sentido los jueces ingleses son capaces de promover el desarrollo del Derecho solo si los abogados de las partes les alientan a ello y ponen a su disposición los materiales jurídicos de que puedan servirse (ya consistan en casos ingleses, otros juicios del Common Law, Derecho comparado o doctrina). Por cierto, existen excepciones a esto, en las que resulta claro que los jueces se han valido de su propia lectura para incorporar proposiciones jurídicas en sus sentencias, pero esto es relativamente raro por un motivo sensato: los jueces que hacen uso de materiales o ideas que no han sido discutidas ante los mismos arriesgan la crítica de denegar a una o ambas partes el derecho a responder ${ }^{59}$.

En tercer lugar, sin embargo, en buena parte del Derecho privado inglés (es decir, el área del Derecho que no es criminal ni administrativa ${ }^{60}$ ), la declinación y derrumbe del jurado ha producido un impacto significativo en la clase de Derecho que debía desarrollarse. En efecto, aunque en los juicios civiles el jurado tenía que resolver los problemas de hecho y los jueces decidir los aspectos jurídicos, la división entre los hechos y el Derecho podía convertirse fácilmente en una función (al menos en parte) de la percepción judicial sobre la apropiada distribución de tareas entre ambos órganos decisorios ${ }^{61}$. Paradójicamente, la presencia o ausencia del jurado ha operado de diversas formas y en distintos contextos para incentivar a los jueces a elaborar el Derecho, descubriendo nuevos problemas jurídicos, y que previamente habían sido vistos como asuntos fácticos más generales. Así, por ejemplo, en materia de formación del consentimiento necesario para la existencia de un contrato, los juristas ingleses tomaron prestada la terminología de oferta y aceptación del Derecho civil ${ }^{62}$, pero en vez de dejar la

\footnotetext{
59 Esto aparece claramente en el discurso de Lord Goff de Chieveley en Spring v. Guardian Assurance Plc. (1995) 2 AC 296, p. 316. En su opinión, en los hechos la fuente del deber de cuidado del demandado descansa en el principio de asunción de responsabilidad derivado de Hedley Byrne \& Co. Ltd. v. Heller \& Partners Ltd. (1964) AC 465, pero a él preocupaba que este principio no había constituido el fundamento de la demanda deducida ante el Comité de Apelación. Lord Goff señaló que normalmente habría invitado a las partes a presentar alegaciones sobre este punto, pero aunque no lo había hecho (en el interés de mantener bajos los costos pues los demás miembros del Comité aceptaron el resultado), él se sentía habilitado para manifestar su juicio sobre cómo debía darse aplicación a este principio, aunque añadiendo que: "deseo enfatizar que la opinión que expresaré en este fallo ha sido formada sin el beneficio del argumento de los abogados, de modo que en tal medida debe ser considerada de autoridad limitada".

${ }^{60}$ El rol del jurado, aunque bajo amenaza, sigue siendo decisivo en los juicios criminales. El Derecho administrativo inglés evolucionó en torno a un procedimiento especial (órdenes judiciales prerrogativas) en donde los jurados no jugaban papel alguno. Una restricción posterior afectó los casos iniciados ante la Chancery Division de la High Court (especialmente sobre derechos de propiedad o fideicomisos), en los que el jurado nuevamente carecía y carece de toda función.

${ }^{61}$ Véase, por ejemplo, respecto de las sentencias sobre "negligencia", infra n. 66 y n. 67.

${ }^{62}$ SiMPSON (1975); IBBETSON (1999) pp. 222-223.
} 
cuestión del "acuerdo" como un hecho para la determinación del jurado, los jueces construyeron una serie de normas relativas a la distinción entre una oferta real (susceptible de aceptación) y una mera "invitación a negociar" (incapaz de ser aceptada) ${ }^{63}$, rechazando que el silencio pudiese constituir aceptación ${ }^{64}$ y estableciendo que una aceptación hecha mediante correo público surtía efecto desde su envío ${ }^{65}$. Pudiera pensarse que estas reglas fueron diseñadas para evitar la incertidumbre en las transacciones que podría haberse generado si el "acuerdo" en general hubiese sido confiado al jurado. Por otra parte, en otros escenarios existió cierta tendencia a expresar el Derecho de modo tal que pudiese ser utilizado en forma de preguntas apropiadas dirigidas a un órgano compuesto por personas profanas. Así, por ejemplo, una vez que se había explicado al jurado el estándar de responsabilidad del "hombre razonable" en el ilícito de negligencia, aquel debía determinar si el demandado había sido negligente ${ }^{66}$; en cambio, cuando los jueces asumieron completamente la tarea de resolver en materia de negligencia, elaboraron los factores adecuados que debían tomarse en consideración para decidir si el demandado había sido culpable, construcción propia de su discreción judicial que en la actualidad a menudo es aludida como análisis "costo/beneficio" 67 . En su conjunto, la eliminación de los jurados ha conducido a cierta inclinación por parte de los tribunales hacia la "juridificación", escindiendo los aspectos jurídicos de los asuntos fácticos más generales o estructurando vastos problemas de evaluación de la calificación de hecho a través de grupos de factores normativamente relevantes.

\section{LA DOCTRINA INGLESA DEL PRECEDENTE}

En esta sección examinaré la postura formal respecto de la doctrina del precedente, tanto en términos de la jurisprudencia inglesa como de otra jurisprudencia del Common Law.

\subsection{LA DOCTRINA FORMAL DEL PRECEDENTE}

Dos son los elementos principales en la doctrina inglesa del precedente, esto es, el conjunto de normas con arreglo a las cuales los fallos anteriores pueden ser vinculantes para el proceso decisorio posterior.

El primer elemento identifica la parte de la sentencia capaz de obligar. La distinción central aquí es entre la ratio decidendi y el obiter dicta: la ratio decidendi tiene la aptitud de vincular el proceso de decisión de un tribunal posterior (dependiendo de las posiciones relativas de los tribunales en la jerarquía), mientras que el obiter dicta no obliga aunque tiene cierta "autoridad persuasiva" ${ }^{68}$. La ratio decidendi de un fallo $-\mathrm{o}$ sus fundamentos- puede ser definida como la proposición o proposiciones de Derecho

\footnotetext{
${ }^{63}$ Hyde $v$. Wrench (1840) 3 Beav. 334 (no en el contexto de jurado de juicios).

${ }^{64}$ Felthouse v. Bindley (1862) 11 CBNS 869.

65 Adams v. Lindsell (1818) 1 B. \& Ald. 681.

${ }^{66}$ IBBETSON (1999) pp. 190-193; WHITTAKER (2005) pp. 189-190.

67 WHITTAKER (2005) pp. 192 y ss.

68 Véase Cross y HARRIS (1990) Cap. III, quienes explican algunos de estos matices.
} 
necesarias para disponer del caso conforme a los hechos ${ }^{69}$. En este punto utilizo la frase relativamente neutra de "proposición de Derecho" con el objeto de reconocer que a veces la ratio puede ser expresada como una "regla", en otras oportunidades como una definición de un concepto jurídico (o de un aspecto del mismo) y en otras ocasiones incluso como un enunciado jurídico mucho más extenso, digno de ser llamado principio. La expresión "disponer el caso" es empleada para poner en claro que la sentencia puede envolver cuestiones de sustancia jurídica (vg. ¿la promesa hecha por el demandado fue contractualmente obligatoria por fundarse en una consideration?) o del remedio jurídico disponible (vg., ¡es posible solicitar el cumplimiento en especie de la obligación en circunstancias que el demandado no honró su promesa?). Bien puede pensarse que en algunos casos se requiere de más de una "proposición de Derecho" para la "disposición" del litigio en este sentido, de modo que, por ejemplo, a fin de obtener el cumplimiento en especie en las ilustraciones recién mencionadas, el actor debe demostrar la existencia de un contrato jurídicamente vinculante, que el demandado no cumplió uno de sus términos y que (en los hechos) podía exigirse el cumplimiento en especie de este ${ }^{70}$. Sin embargo, un tribunal normalmente decidirá todas las cuestiones que han sido debatidas ante él, incluso si su opinión respecto de una de estas torna las demás en redundantes (por ejemplo, sin contrato, ex hypothesi no puede haber una cláusula incumplida ni ejecución forzada). Las decisiones acerca de estos otros problemas (que pueden ser importantes para las mismas partes si no son controvertidas al invalidarse la primera cuestión en la apelación) carecerán de la fuerza de ratio desde la primera sentencia, porque no fueron necesarias para la resolución del caso conforme a los hechos y, en consecuencia, fueron formalmente obiter.

Sin embargo, el aspecto crucial de la definición arriba enunciada es que la ratio de un caso vincula las proposiciones de Derecho discutidas en una o más sentencias con los hechos y las reclamaciones de las partes. Estas dos conexiones necesarias delinean los límites de la fuerza obligatoria de las proposiciones en el texto de los fallos. Obiter dicta son todas aquellas proposiciones de Derecho en las sentencias que carecen de la fuerza de ratio.

Esto significa, primero, que los hechos de un caso componen algo que excede con mucho un simple contexto: ellos juegan una función decisiva al determinar la fuerza futura del proceso. Así, la fuerza obligatoria del precedente reconoce la particularidad inherente de todo desarrollo jurídico efectuado en el curso del litigio, en el cual los jueces tienen en mente las circunstancias y, puede decirse, el resultado deseado del pleito de que conocen. ¿Quién, sin embargo, determina la ratio de un caso? En ciertas ocasiones uno o más jueces en la misma causa tratarán de aclarar lo que consideran como las proposiciones jurídicas críticas para su resolución, quizá incluso explicando la extensión de estas y comentando explícitamente su relación con el Derecho en general. No obstan-

\footnotetext{
${ }^{69}$ Cf. la definición en BeLL (2000) n. 7, pp. 28-29: "(un) precedente es una declaración sobre un punto de Derecho establecida en una sentencia judicial como la justificación del resultado que se alcanza en ese caso". Véase además: Cross y HARRIS (1990) Cap. II.

70 Cf. Cross y Harris (1990) pp. 41-42.
} 
te, en definitiva corresponde a los jueces que conocen de procesos posteriores fallar basándose en las rationes decidendi de sentencias anteriores, identificando una o más proposiciones de Derecho que fueron necesarias para su decisión de los hechos según estos fueron establecidos por el tribunal anterior. En efecto, sobre todo cuando un tribunal posterior es de inferior jerarquía que el que resolvió el caso precedente, aquel debe determinar las proposiciones que configuraron su ratio para así seguirla. Como un corolario, existen dos maneras en que un tribunal posterior puede evitar la aparente aplicabilidad de una proposición jurídica tal como fue enunciada en un pleito anterior. Puede sostener que la proposición jurídica contenida en el caso precedente, que parece corresponder a los hechos de que conoce, no formó parte de la ratio del fallo anterior y, por tanto, no obliga; o puede declarar que la proposición jurídica en el caso precedente en realidad integró la ratio de la sentencia anterior, pero que los hechos del caso actual son distinguibles de los hechos del caso anterior, esto es, distintos en una forma jurídicamente relevante. En consecuencia, las proposiciones jurídicas contenidas en las sentencias inglesas se supeditan a los hechos en un doble sentido: su fuerza vinculante depende de su relación con los hechos del fallo en el cual ellos fueron declarados y de su relación con los hechos del juicio en que posteriormente se alega su aplicación. Dado que en último término son únicamente los tribunales posteriores quienes identifican las proposiciones jurídicas que aprueban este doble examen, puede notarse que la fuerza obligatoria de los precedentes es un tanto frágil como también contingente.

El segundo elemento principal de la doctrina del precedente en el Derecho inglés es el rol de la jerarquía judicial. Este puede exponerse brevemente ${ }^{71}$. Primero, un tribunal está obligado a seguir todo caso (esto es, la ratio según recién fue explicada) resuelto por un tribunal anterior de superior jerarquía y los tribunales de apelación -diversos de la Cámara de los Lores- están vinculados por sus propios fallos previos ${ }^{72}$. Esto significa, vg., que las sentencias pronunciadas por la Cámara de los Lores son vinculantes para los

${ }^{71}$ Para una discusión completa, véase CROSS y HARRIS (1990) cap. III.

72 CROSS y HARRIS (1990) p. 96. Una excepción a esta postura se produce cuando un caso anterior es fallado per incuriam, según ha sido explicado supra 1.3, p. 12, circa n. 58. Un juez de la High Court no está obligado por las resoluciones de otros magistrados del mismo tribunal, pero "salvo que esté convencido de que el fallo es erróneo, (él) lo seguiría como un asunto de deferencia judicial": Huddersfield Police Authority v. Watson (1947) KB 842, p. 848, citado por CROSS y HARRIS (1990) p. 122. Estos autores (pp. 97-98) explican las diferencias entre la fuerza obligatoria de la ratio de un juicio anterior y los límites de la doctrina res judicata, por la cual las partes de un litigio previo están impedidas (por un "problema de estoppel") de reanudar la discusión de la sentencia pronunciada en ese pleito. "Las diferencias fundamentales conciernen a la jerarquía judicial y la extensión de quienes son afectados. Únicamente rationes decidendi emanadas de tribunales superiores crean precedentes vinculantes, pero estos tienen aplicación sobre todos los que están incluidos en su ámbito. Una 'demanda de estoppel' o un 'incidente de estoppel' solo puede ser alegado por las partes directamente afectadas por el fallo anterior, pero este determina sus derechos aunque haya sido dictado por un funcionario con competencia reducida". Cf. la actitud de algunos iusprivatistas franceses quienes emplean el efecto limitado de la chose jugée, previsto en los artículos 1350 y 1351 del CODE, como argumento en contra de la fuerza obligatoria más amplia de la jurisprudence: CARBONNIER (1990) p. 248, considera que el principio de l'autorité relative de la chose jugée opera en contra de las sentencias que crean normas de Derecho: "le jugement n'a d'autorité, de force juridique, qu'entre les personnes qui ont été parties aux procès, il n'est pas opposable aux tiers". 
tribunales superiores de primera instancia ${ }^{73}$ y la Corte de Apelaciones; y que la Corte de Apelaciones está obligada por sus propias resoluciones ${ }^{74}$. Hasta 1966 la Cámara de los Lores se consideraba a sí misma obligada por sus propias sentencias, pero en ese año determinó, mediante una famosa Declaración de Práctica, no encontrarse obligada por sus fallos, aunque de hecho ha sido muy renuente a invalidarlos ${ }^{75}$. El sentido en que una ratio es obligatoria es que los jueces ingleses consideran que estas normas de precedente (tanto en términos de definir la ratio decidendi de un caso anterior como de la jerarquía de los tribunales) deben ser acatadas y poseen una "visión interna" de estas ${ }^{76}$. A pesar de que no existe una sanción formal para un juez que omite aplicar un precedente en el sentido aludido (aunque un ofensor reiterado podría ser depuesto de su cargo), no es un hecho menor que él quedaría expuesto a la crítica de sus colegas magistrados y de la comunidad jurídica en general.

Sin embargo, ninguna explicación formal de la doctrina del precedente puede ser cabal si no menciona la trascendencia de aquellos elementos de una sentencia que no integran su ratio decidendi y que son descritos formalmente como obiter dicta. En efecto, si bien las declaraciones de Derecho emitidas por los tribunales superiores y que no forman parte de la ratio de un fallo carecen de obligatoriedad, retienen eso sí una autoridad persuasiva y que, ocasionalmente, es muy considerable. Su autoridad depende en parte del rango del tribunal que dicta la sentencia, en parte del respeto personal brindado al juez individual (especialmente si está opinando en una materia jurídica en la que se ha destacado ${ }^{77}$ ), pero por sobre todo del grado en que el significado sustancial de

\footnotetext{
73 Particularmente, la High Court.

74 Young v. Bristol Aeroplane Co. Ltd. (1946) AC 163, p. 169; Farrell v. Alexander (1977) AC 59, pp. 92 y 105.
}

75 Declaración de Práctica (Precedente Judicial) (1966) 1 WLR 1234. Lord Bingham de Cornhill ha declarado recientemente que "la infrecuencia con que la Cámara (de los Lores) ha ejercido su libertad para desviarse de sus propias sentencias pone de relieve la importancia que ella atribuye al principio (del precedente)": Leeds City Council v. Price cit. n. 1, párr. 42. HARris (2002) postula que la Cámara de los Lores debiera sentirse más libre para revocar sus "resoluciones erróneas" pretéritas, incluso si no puede apelar a hechos distinguibles, cambios en la sociedad, alteraciones en los principios jurídicos pertinentes, per incuriam o aducir que el fallo anterior ha devenido impracticable. Este autor expone una serie de aspectos que, en su concepto, los jueces de apelación de la Cámara de los Lores debieran tomar en cuenta al decidir si van a actuar de la forma antes indicada, agregando que no debieran preferir la mantención de "precedentes erróneos" en los intereses de la certeza jurídica (los "valores del stare decisis") sino que debieran anularlos en aras de la justicia. Así definido, el tipo de caso aludido por Harris es inusual, porque los diversos elementos a que puede echarse mano rara vez faltan (con un leve ajuste o imaginación de los lores). Sin embargo, en mi opinión, los jueces de apelación de la Cámara de los Lores probablemente deciden la clase de pleitos que preocupa a Harris en forma ad hoc, sopesando los méritos sustantivos del cambio contra sus deméritos tomados en su conjunto y teniendo en cuenta los argumentos prácticos y constitucionales a favor y en contra de la modificación judicial contrastada con la legislativa. Para este fin, es inútil adoptar una presunción a favor de la anulación de una sentencia anterior "errónea" o de su confirmación en los intereses de la certeza jurídica.

76 CROSS y HARris (1990) p. 98, tomando prestada la famosa expresión de HART (1961) p. 86.

77 Un ejemplo aquí puede identificarse en el caso de las sentencias dictadas por Lord Goff de Chieveley sobre enriquecimiento sin causa, en su condición de autor (junto al profesor Gareth Jones) de la obra fundamental en esta materia en el Derecho inglés, Goff and Jones on Restitution, publicada inicialmente como The Law of Restitution en GOFF y JONES (1966). 
las proposiciones contenidas en el dicta persuaden al juez posterior. Pues, cuando un tribunal considera que una proposición jurídica no compone la ratio, la auténtica eficacia de su autoridad proviene tanto de su contenido sustantivo como de su origen.

\subsection{EL ESTATUS DE LA JURISPRUDENCIA DE OTRAS JURISDICCIONES DEL COMMON LAW ANTE LOS TRIBUNALES INGLESES}

Una fuente adicional de autoridad "persuasiva" es descubierta por los tribunales ingleses en los fallos de otras jurisdicciones del Common $L_{a w^{78}}$. El motivo por el que estas decisiones pueden poseer tal "autoridad persuasiva" estriba en que los jueces en estas jurisdicciones han trabajado y continúan operando con los mismos fundamentos en el Common Law; de hecho, en el caso de muchos tribunales del Commonwealth, hasta hace relativamente poco tiempo la apelación final estuvo radicada en el Comité Judicial del Privy Council (o el "Directorio" del Privy Council) en Londres" ${ }^{79}$, el cual -según pudo apreciarse- fue proclive a desestimar cualquier discriminación entre el Derecho inglés y los “common laws" del Commonwealth ${ }^{80}$. Con todo, la denegación formal por los tribunales ingleses de todo carácter vinculante de los precedentes emanados de otras jurisdicciones del Common Law alcanza incluso las sentencias del Privy Council cuando este conoce de apelaciones sobre el Common Law "extranjero" que es tratado idénticamente al Common Law de Inglaterra, aunque estos precedentes son a menudo analizados con la mayor deferencia, especialmente porque los jueces que contribuyen al "consejo" del Privy Council (formalmente a su Majestad la Reina) suelen ser exactamente los mismos magistrados que tendrían que resolver el asunto de haber este sido sometido al Comité Judicial de la Cámara de los Lores ${ }^{81}$. La superposición de funcionarios entre ambos tribunales (e incluso su especial estructura) tiene en sí misma importancia. Así, por ejemplo, en $R v$. Blastland Lord Bridge observó que si bien el fallo del Privy Council "en el caso Ratten" 82 técnicamente no es obligatorio para la Cámara de los Lores, la constitución del Directorio (Lord Reid, Lord Hodson, Lord Wilberforce, Lord Diplock y Lord Cross) goza de la más alta autoridad persuasiva" 83 .

No obstante, en otro tipo de situaciones, el Derecho que el Privy Council debe declarar difiere claramente del propio Derecho inglés, aun si la diferencia es muy tenue. Por ejemplo, en Invercargill City Council v. Hamlin ${ }^{84}$ el Privy Council sostuvo que, para determinar el Derecho de Nueva Zelanda sobre la responsabilidad de una autoridad local por el ilícito de negligencia al haber omitido inspeccionar los cimientos de un edificio, no

${ }^{78}$ Vg. Llonrho plc v. Fahed (No 4) (1994) 1 All ER 870, p. 879 (fallado por la High Court y la Corte Suprema de Australia).

${ }^{79}$ Este sigue siendo el caso para un grupo de países pequeños de la Commonwealth.

${ }^{80}$ CROSS y HARRIS (1990) pp. 23-24.

${ }^{81}$ Vg. sentencia del Privy Council en Pao On v. Lau Liu Long (1980) AC 614 (sobre las doctrinas de la consideration y de la coacción económica en el Derecho de los contratos), cuyo enfoque acerca de una dimensión de la doctrina de la consideration fue seguida por la Corte de Apelaciones inglesa en vez del antiguo precedente inglés en Stilk v. Myrick (1809) 2 Camp. 317: infra 3.3, p. 28, circa n. 150 a n. 157.

82 (1971) 3 All ER 801.

83 (1986) AC 41, p. 58 (énfasis agregado).

84 (1996) AC 624 
seguiría el fallo de la Cámara de los Lores directamente vinculado con la materia ${ }^{85}$, porque hacía unos veinte años que la Corte de Apelaciones de Nueva Zelanda (que a la sazón era el máximo tribunal en este país) había dirigido el Derecho por un camino diferente ${ }^{86}$. Lord Lloyd de Berwick advirtió, en representación del Directorio, que:

Cuando la Corte de Apelaciones de Nueva Zelanda pretende aplicar principios establecidos del Common Law inglés, el Directorio debe asegurar que dichos principios sean empleados correctamente ${ }^{87} \ldots$ Sin embargo, en el presente caso los jueces de la Corte de Apelaciones de Nueva Zelanda conscientemente se desviaron de la jurisprudencia inglesa aduciendo que en Nueva Zelanda las condiciones son distintas. ¿Estaban facultados para actuar así? La respuesta sin duda debe ser "sí". La aptitud del Common Law para adaptarse a las contrastantes circunstancias de los países en que ha echado raíces no es una debilidad sino una de sus mayores fortalezas $^{88}$.

Por el contrario, sin embargo, cuando es el caso, la elocuencia de estas nuevas orientaciones jurisprudenciales probablemente decrece en el contexto inglés.

\section{EL USO DEL PRECEDENTE EN INGLATERRA}

En este acápite intentaré explicar algunas de las características clave del uso del precedente por los jueces ingleses (en ambos sentidos identificados previamente), el que no surge, al menos completamente, de la descripción formal de las normas. Para este propósito dividiré mi exposición bajo cinco epígrafes.

\subsection{Multiplicidad DE Litigios, MulTipliCidAd DE SENTENCIAS}

La descripción formal de la doctrina del precedente podría fácilmente llevar a creer que un juez inglés, al resolver, tiene que identificar el caso anterior pertinente, determinar si las proposiciones de Derecho contenidas en la sentencia respectiva están conectadas suficientemente con los hechos como para constituir su ratio y, luego, si los hechos no difieren significativamente del caso actual, aplicar esa proposición a los hechos de que conoce. Sin embargo, lo primero que uno nota al examinar diversas áreas sustantivas del Derecho inglés, es el número de casos y la cantidad y complejidad de resoluciones que estos contienen. Por supuesto, a veces estos casos simplemente siguen una tendencia jurisprudencial asentada, aplicando -en forma obediente y no controvertida- una postura establecida a grupos de hechos nuevos o levemente distintos. En otras

\footnotetext{
${ }^{85}$ I.e. Murphy v. Brentwood District Council (1991) 1 AC 398.

86 (1996) AC 624, p. 635 (por Lord Bridge).

${ }^{87}$ Lord Lloyd de Berwick consideró en tal sentido las resoluciones del Privy Council en Hart v. O'Connor (1985) AC 1000 y las observaciones de Lord Scarman en Tai Hing Cotton Mill Ltd. v. Liu Chong Hing Bank Ltd. (1986) AC 80, p. 108.

88 (1996) AC 624, p. 640. Cf. Hart v. O’Connor (1985) AC 1000, p. 1027 (donde el Privy Council y los tribunales neozelandeses discreparon en un aspecto de la norma sobre capacidad contractual).
} 
oportunidades, en cambio, más que corresponder a una simple dirección jurisprudencial, los casos resueltos pueden ser mejor descritos como creando un modelo de autori$\mathrm{dad}$, en el que las sentencias establecen (o revelan) normas y excepciones, principios y limitaciones, para cuyo efecto distinguen según el contexto fáctico o jurídico. Asimismo, a veces los casos manifiestan contrastes significativos de enfoque y/o política, de modo que aun si los mismos fallos pueden ser conciliados formalmente con la doctrina del precedente (mientras que los contextos de estas diversas visiones difieren en forma significativa $y$, es posible, pertinente), ellos parecen ofrecer al juez posterior una opción sobre la manera de proceder. Incluso esto puede ocurrir en un mismo juicio, especialmente si los miembros de la Cámara de los Lores discrepan no solo en cuanto al resultado que debe alcanzarse en los hechos que enfrentan, sino también (aun dentro de la mayoría) respecto de las razones que justifican tal conclusión. Cuando esto sucede la precisión de toda ratio por el fallo es realmente muy difícil. En suma, en diversas situaciones, el problema para un juez inglés no es el clásico asunto teórico del caso no resuelto en que los precedentes no le enseñan cómo debiera decidir, sino que es el caso regulado en exceso, verdaderamente demasiados juicios relevantes que compiten por atraer la atención, los cuales son a veces auténticamente distinguibles conforme a su ámbito, pero en ocasiones revelan contrastes significativos de criterio o valoración de las políticas rivales que pugnan por su aplicación.

Ofreceré un ejemplo reciente de un litigio resuelto por la Cámara de los Lores, el que puede ilustrar estos fenómenos (aunque en un grado inusual) y el hecho de que al proceder así los jueces no se disculpan por descender en considerables detalles sustantivos, porque esto refleja la realidad de muchos pleitos ingleses (particularmente de los juicios importantes ventilados ante la Cámara de los Lores).

En Shogun Finance Ltd. v. Hudson, un embaucador ingresó a un establecimiento de venta de automóviles expresando su interés en comprar un vehículo a crédito ${ }^{89}$. El individuo se presentó como el Sr. Durlabh Patel (persona real por quien se hacía pasar), exhibiendo como identificación una licencia de conducir hurtada. El vendedor telefoneó a la sociedad financiera de costumbre y luego le envió por fax un formulario firmado por el embaucador como Sr. Patel. Con base en confirmaciones de crédito realizadas por la sociedad financiera, el vendedor accedió a celebrar un contrato de arrendamiento con opción de compra de automóvil con el Sr. Patel/embaucador (la forma en que esto se expresa es relevante), para lo cual enajenó el vehículo a la sociedad financiera. El embaucador pagó un diez por ciento del precio en efectivo y giró un cheque por el saldo (que luego no pagaría), tomó el automóvil y posteriormente lo vendió a Hudson, un particular que lo compró de buena fe. La sociedad financiera demandó a Hudson la indemnización de los perjuicios por apropiación ilícita, esto es, un delito (civil) que afectaba su título sobre el vehículo. La disyuntiva fundamental que la Cámara de los Lores debió resolver era si Hudson había adquirido un título sobre el vehículo cuando lo había comprado del embustero. El resultado fue claro: tres de los cincos jueces que integraron la Cámara de los Lores declararon que el embaucador no había adquirido título y, por

89 (2003) UKHL 62; (2004) 1 AC 919. 
ende, en esas circunstancias mal podía este haber sido transferido a Hudson, como consecuencia de la máxima nemo dat quod non habet. Con todo, el razonamiento de la mayoría varió muy significativamente entre los jueces que concurrieron a la misma. Por su parte, los argumentos de la minoría parecieron ser sustancialmente convincentes (¡incluso para un juez de la mayoría! ${ }^{90}$ ), más en sintonía con la autoridad y pensamiento contemporáneos, y reflejar un mejor equilibrio entre los intereses de las partes en conflicto en esta clase de litigios.

Permítaseme comenzar con la minoría (Lord Nicholls de Birkenhead y Lord Millett), cuya es la posición más directa. Ambos analizaron este asunto como el clásico problema del efecto que produce el error en la identidad de una persona sobre la validez de un contrato (en los hechos, el error incurrido por la sociedad financiera al creer que la persona que había suscrito el instrumento contractual era el Sr. Patel): ¿dicho error en la identidad del otro contratante de un supuesto contrato acarreaba la nulidad de este o (si derivaba de una falsa representación) meramente lo hacía anulable por dolo? Si el contrato era nulo por error, luego ningún título pasaba al embaucador ni, por tanto, al tercero inocente; si el contrato era anulable por dolo, entonces el embaucador adquiría título mientras el contrato no fuese rescindido (instante en que el título retornaría al vendedor), aunque la presencia del interés de un tercero en la propiedad impediría la rescisión. No obstante que, en palabras de Lord Nicholls, en este respecto el Derecho era "notoriamente deficiente"91, la minoría estuvo de acuerdo con lo resuelto por la Corte de Apelaciones, la que había declarado que el contrato entre presentes se entendía celebrado entre quienes están el uno frente al otro ${ }^{92}$; y, como no pudieron notar diferencia alguna con la situación en que el contrato resultante constaba por escrito (que es como interpretaron los hechos) ${ }^{93}$, prefirieron seguir a la Corte de Apelaciones (en casos relativos a contratos entre presentes) y no a la sentencia de la Cámara de los Lores recaída en Cundy v. Lindsay ${ }^{4}$, que había fijado la presunción de que una persona intenta negociar con aquella cuyo nombre figura en la correspondencia, de tal modo que si quien firma no es esta última, el contrato es nulo ${ }^{95}$. En opinión de la minoría, esta resolución de la Cámara de los Lores no debía ser más observada en lo sucesivo ${ }^{96}$, pues no era "justa (para los terceros inocentes) ni fundada, y no todos los precedentes de los que emanaba podían ser conciliados"97.

\footnotetext{
${ }^{90}$ Lord Phillips: infra p. 21, circa n. 98 a n. 104.

91 (2003) UKHL 62 párr. 1.

92 Phillips v. Brooks Ltd. (1919) 2 KB 243; Lewis v. Averay (1972) 1 QB 198. Incluso aquí, la minoría tuvo que desechar la sentencia de la Corte de Apelaciones en Ingram v. Little (1961) 1 QB 31, donde terceros inocentes (dos ancianas) hicieron cuanto pudieron por verificar la identidad de un embaucador antes de celebrar la transacción.

93 (2003) UKHL 62, párr. 18.

${ }_{94}$ Cundy v. Lindsay (1878) 3 App.Cas 459 HL(E).

95 Aquí hubo una diferencia aparente pues Lord Millett consideró que "algo había que decir para que la presunción deviniese concluyente”: (2003) UKHL 62 p. 67.

96 (2003) UKHL 62 párr. 36 (Lord Nicholls); (2003) UKHL 62 párrs. 83, 108-110 (Lord Millett).

97 (2003) UKHL párr. 84 por Lord Millett.
} 
Contrastando con esta unanimidad relativa, los jueces de la mayoría discreparon entre sí acerca del problema jurídicamente relevante. Lord Phillips de Worth Matravers coincidió con la minoría (Lord Nicholls y Lord Millett) que la duda consistía en si un error en la identidad de la otra parte de un supuesto contrato lo tornaba nulo por error o meramente anulable por dolo, pero disintió sobre la forma en que debía ser decidida. Su punto inicial fue que los contratos requerían de un consensus ad idem, concebido normalmente en términos objetivos, a la manera clásicamente inglesa, en que el tribunal examinaba imparcialmente los intercambios de voluntad: “(a)sí como debe acreditarse que las partes han convenido en los términos del contrato, así también debe probarse que ambas han consentido recíprocamente. Si $\mathrm{A}$ hace una oferta a $\mathrm{B}$, pero es $\mathrm{C}$ quien se propone aceptarla, no existe contrato" 98 . Sin embargo, tras analizar once causas anteriores consideradas pertinentes para resolver el asunto, Lord Phillips se sintió "fuertemente atraído" por la solución de la minoría ${ }^{99}$ (la que habría implicado apartarse de Cundy v. Lindsay bajo el pretexto de tratarse de un fallo desacertado), pero concluyó que había que distinguir los contratos entre presentes (en los que se presume -admitiéndose prueba en contrario- que las partes pretenden contratar con la persona que está frente a la otra) ${ }^{100}$ de los contratos celebrados por escrito (en los que, en principio, el documento debía dejar de manifiesto la intención de las partes en cuanto a la identidad) ${ }^{101}$. En efecto, "Cundy v. Lindsay muestra cómo el Derecho inglés utiliza un mismo enfoque para identificar a las partes y para identificar los términos del contrato"102. Así, el "principio objetivo" de interpretación y la importancia concedida a los términos escritos primaba por sobre lo que Lord Phillips estimó como una "solución elegante (de la minoría) a (la) incongruencia" que significa discriminar entre las formas en que se celebran las transacciones ${ }^{103}$. Aplicando esta norma a los hechos, Lord Phillips consideró que la sociedad financiera no había celebrado un contrato entre presentes con el embaucador pues habían mantenido correspondencia por escrito y, por ende, el contrato era nulo por error ${ }^{104}$. Cabe señalar, sin embargo, que en parte alguna de su discurso Lord Phillips aceptó los argumentos expuestos por los demás jueces que concurrieron en el voto de mayoría.

Los dos otros jueces de la mayoría, Lord Hobhouse de Woodborough y Lord Walker de Gestingthorpe, arribaron al mismo resultado, pero por rutas muy distintas. Así, Lord Hobhouse (con quien Lord Walker concordó, aunque agregando sus propias observaciones) ${ }^{105}$ sostuvo que "los casos sobre el error en la identidad" eran simplemente irrelevantes en el presente juicio, pero de pasada, en relación a dos de esos pleitos, expresó que "las observaciones de Devlin LJ en Ingram v. Little $e^{106}$ no son pertinentes; el criterio y la resolución de Lord Denning MR en Lewis v. Averay ${ }^{107}$ están fuera de lugar y

\footnotetext{
98 (2003) UKHL párr. 125, por Lord Phillips.

99 (2003) UKHL párr. 170.

100 (2003) UKHL refiriéndose a una "presunción fuerte" para estos efectos.

101 (2003) UKHL

102 (2003) UKHL párr. 170.

103 (2003) UKHL párrs. 169-170.

104 (2003) UKHL párrs. 178-179.

105 (2003) UKHL párr. 180.

106 (1961) 1 QB 31.
} 
son equivocados"108. Sin embargo, Lord Hobhouse consideró que este era primordialmente un asunto de interpretación de ley y de aplicación de importantes y consolidados principios del Derecho inglés de los contratos, los que no se centraban en el error en la identidad ${ }^{109}$. En su opinión, el problema medular era si el tercero había adquirido un título sobre el automóvil en virtud de la transacción celebrada con la sociedad financie$\mathrm{ra}^{110}$. Como este era un contrato de arrendamiento con opción de compra y no una compraventa, a la luz del mismo, el embaucador no había adquirido título a la época en que había contratado con el tercero inocente, título que el "arrendatario/deudor" ganaría únicamente con el ejercicio de la opción de compra ${ }^{111}$. El asunto devino en si este caso quedaba cubierto por la excepción especial a la regla nemo dat quod non habet, que el artículo 27 de la Ley sobre Arrendamiento con Opción de Compra de 1964 contemplaba para el supuesto de un "deudor" bajo dicho contrato ${ }^{112}$. Lord Hobhouse respondió en la negativa: el embaucador obviamente no era "el deudor" porque el instrumento escrito designaba en ese carácter al Sr. Patel (lo que no era cierto). Por lo tanto, el principio jurídico más vasto que debía ser aplicado no admitía (en general) la prueba oral para refutar los términos de un contrato escrito, lo que Lord Hobhouse calificó como "una de las grandes fortalezas del Derecho comercial inglés"113. Por último, este juez sustentó su visión de los hechos en la ausencia de todo consensus ad idem entre las partes, ya que no había habido oferta alguna del Sr. Patel susceptible de se aceptación por la sociedad financiera ${ }^{114}$.

Como he indicado, Lord Walker formalmente estuvo de acuerdo con los argumentos de Lord Hobhouse, pero con distinto énfasis. El raciocinio de Lord Walker no descansó en la trascendencia de la pretensión de que el contrato entre la sociedad financiera y el embaucador fuese un arrendamiento con opción de compra y no una compraventa $^{115}$. Por el contrario, su punto de partida fue la imposibilidad de adoptar una postura general sobre cuál de las dos partes inocentes era merecedora de mayor protección contra el dolo perpetrado por el embaucador, porque esto dependía especialmente de si ellas habían participado o no en el negocio ${ }^{116}$. A la inversa, la dificultad esencial concernía a la oferta y la aceptación, interpretadas objetivamente; de modo que, en lo concreto, la pregunta pertinente era a quién se había intentado formular la oferta. En su concepto, la respuesta a esta cuestión difería según si se trataba de contratos entre presentes (en los cuales rige una firme presunción - pero que puede ser contrarrestadade que uno intenta contratar con la persona presente) ${ }^{117}$ o de contratos por correspon-

\footnotetext{
107 (1972) 1 QB 198.

108 (2003) UKHL 62 párr. 47. Véase también párr. 55.

109 (2003) UKHL párr. 55.

110 (2003) UKHL párr. 42.

111 (2003) UKHL párr. 42.

112 (2003) UKHL párrs. 43-44.

113 (2003) UKHL párr. 49.

114 (2003) UKHL párr. 50.

115 Él sí lo mencionó, pero indirectamente: (2003) UKHL párr. 182.

116 (2003) UKHL párr. 182.

117 (2003) UKHL.
} 
dencia, en los que "la oferta y la aceptación deben descubrirse, si han de encontrarse, en los términos de los documentos" 118 . Aunque pueden existir casos más difíciles, en los hechos concretos ante Lord Walker "(l)a forma del contrato dejaba absolutamente claro que la intención (de la sociedad financiera) fue aceptar una oferta hecha por el verdadero Sr. Patel y nadie más"119.

¿Cuál es, en consecuencia, la ratio decidendi de Shogun Finance Ltd. v. Hudson? Todos los magistrados (en la mayoría y en la minoría) coincidieron en que se presume que una persona que contrata cara a cara pretende hacerlo con la otra que está presente, aunque disputaron si esta presunción era irrefragable ${ }^{120}$. Desde luego, ninguno de los jueces consideró que los hechos de la causa se ajustaban a la descripción anterior. En cuanto a la decisión sobre estos hechos, si bien una rotunda mayoría acogió la demanda de la sociedad financiera por apropiación ilícita, sus miembros discordaron respecto de sus fundamentos ${ }^{121}$. Lord Hobhouse emitió el dictamen más nítido, pero mientras su principal argumento se sustentó en la presencia de un arrendamiento con opción de compra y en sus normas legales especiales, esto no caracterizó el discurso de Lord Phillips ni ocupó un lugar destacado en el de Lord Walker. Más aún, aunque Lord Hobhouse y Lord Walker opinaron que el fallo dictado en Cundy v. Lindsay debía ser acatado, lo hicieron no tanto debido a su autoridad como sentencia de la Cámara de los Lores, sino más bien por su relación con lo que, entendieron, constituían principios fundamentales del Derecho contractual sobre la naturaleza objetiva de un pacto y su interpretación (especialmente de instrumentos escritos); y Lord Hobhouse, al menos, estimó que este caso no concernía al error en la identidad ${ }^{122}$. No obstante que la mayoría de los jueces apreció el caso de esta manera (ciertamente la minoría más Lord Phillips y, posiblemente, en algún grado, Lord Walker), no estuvieron de acuerdo en la conclusión. Por consiguiente, a nivel técnico, dada la ausencia de una inequívoca ratio decidendi en el fallo de mayoría, Shogun Finance Ltd. v. Hudson no esclarece realmente el estado del Derecho en materia de contratos distintos de aquellos entre presentes. Sin embargo, esta sentencia sí sugiere que en la Cámara de los Lores los precedentes pueden ser concebidos como ilustraciones acerca de la aplicación de criterios y principios antagónicos, cuya evaluación es tarea de los miembros de la Cámara, quienes pueden disentir al respecto y, agregaría, bastante a menudo discrepan. Shogun Finance Ltd. demuestra: que los jueces pueden tener desavenencias acerca del auténtico problema a resolver (error en la identidad, reglas especiales sobre arrendamiento con opción de compra, intención objetiva en la interpretación contractual, oferta y aceptación); la importancia jurídica de las distinciones fácticas (contratos entre presentes y contratos por escrito); y que no se trata meramente de determinar la solución más justa (¿quién debe soportar el riesgo: la persona que entrega una propiedad a crédito o el tercero inocente?), sino

\footnotetext{
118 (2003) UKHL párr. 188.

119 (2003) UKHL párr. 191.

120 Supra n. 95, n. 100 y n. 117.

121 Supra, pp. 20-23, circa n. 92 a n. 121.

122 Supra, pp. 21-22, circa n. 105 a n. 106.
} 
también si es posible aseverar que existe una solución más justa en todas las circunstancias posibles que se subsumen en la cuestión tratada.

\subsection{PRECEDENTE Y PRINCIPIO}

Esta discusión de Shogun Finance Ltd. v. Hudson enseña que, aunque el Common Law es construido a partir de sentencias cuya fuerza vinculante se circunscribe formalmente a una relación entre las proposiciones jurídicas que las soportan y sus hechos (y, por eso, parece crear un Derecho muy particular), en el proceso de decisión judicial inglés en modo alguno falta una apelación a los principios jurídicos ${ }^{123}$. Tal como el desaparecido profesor Lawson observara, "(a)unque los libros rara vez, si alguna, dan un indicio ${ }^{124}$, el Derecho inglés contiene diversas doctrinas de gran extensión que son más potentes que cualquiera de las sentencias en las que se basan o aplican"125. Así, por ejemplo, en el Derecho de contratos, los jueces ingleses aceptan resolutamente un principio de libertad contractual y la fuerza obligatoria de los contratos, pero rechazan categóricamente un principio general de la formación o cumplimiento de buena fe de los contratos ${ }^{126}$. No obstante que pueden citarse decisiones judiciales que reconocen estas proposiciones, su verdadera influencia proviene de su relación con una serie de áreas sustantivas que subyacen al Common Law. Así, por ejemplo, la fuerza obligatoria de los contratos es percibida como el fundamento de la regla en cuya virtud las cláusulas de exención y de limitación pueden excluir la responsabilidad contractual o extracontractual siempre que estén incorporadas en el contrato y que, conforme sus términos, incumban a la responsabilidad correspondiente ${ }^{127}$. La fuerza obligatoria también informa la negativa de conceder toda reparación si hechos sobrevinientes tornan el cumplimiento de un contrato más oneroso, aunque los tribunales ingleses separan esta situación de aquella en que el cumplimiento deviene "radicalmente diferente" de lo que las partes se obligaron a ejecutar, circunstancia en que el contrato resulta "frustrado" 128.

\footnotetext{
${ }^{123}$ En la discusión siguiente me referiré a "principio" en la forma más bien ambigua en que es utilizada por los jueces ingleses y juristas en general, vale decir, como una proposición de Derecho que es suficientemente extensa y de singular importancia. Cf. DWORKIN (1977), quien define especialmente los "principios jurídicos" y los considera centrales en su teoría de la adjudicación. Así, los "(a)rgumentos de principio justifican una decisión política mediante la demostración de que la sentencia respeta o garantiza algún derecho individual o grupal”, a diferencia de los "(a)rgumentos de política (que) justifican una decisión política mediante la demostración de que la sentencia fomenta o protege algún objetivo colectivo de la comunidad en su conjunto" (p. 82). Dworkin luego sostiene que las "decisiones judiciales en casos civiles, incluso en casos difíciles... esencialmente son y deben ser generadas por principios y no por política" (p. 84).

${ }^{124}$ En mi opinión, esto ha disminuido considerablemente desde la época en que escribió el profesor Lawson.

125 LAWSON (1997) pp. 90, 96-97, inicialmente una conferencia ofrecida en 1942.

126 Para un discusión posterior de estos principios y sus excepciones, véase BEALE (2004), párrs. 1-010-1028 (por Whittaker).

127 Suisse Atlantique Société d'Armement Maritime SA v. N.V. Rotterdamsche Kolen Centrale (1967) 1 AC 361; Photo Production Ltd. v. Securicor Transport Ltd. (1980) AC 827, p. 848.

128 Davis Contractors Ltd. v. Fareham UDC (1956) AC 696, p. 716 (por Viscount Simonds); p. 729 (por Lord Radcliffe).
} 
Sin embargo, los tribunales a veces han reconocido los principios jurídicos en una forma más creativa. Así, en el caso más renombrado, Donoghue v. Stevenson, Lord Atkin buscó justificar su decisión manteniendo que un fabricante podía ser responsable por el ilícito de negligencia para con una persona lesionada por el producto de aquel conforme a lo que se conocería como el "principio del vecino"129. Lord Atkin simplemente pudo haber restringido su decisión al caso concreto, pero en lugar de ello consideró que los ejemplos en los litigios resueltos en los que una persona sería responsable por culpa (en que tenía un "deber de cuidado") ilustraban un principio de mayor alcance. Esto le permitió superar al argumento (acogido por Lord Buckmaster en su voto disidente ${ }^{130}$ ) de que el fabricante no debía responder más allá de su contrato y del otro contratante, invitando a tribunales posteriores a agregar nuevos casos de responsabilidad no previstos por decisiones concretas consolidadas ${ }^{131}$. Aunque con posterioridad este principio ha sido sustituido por otros "enfoques" según los cuales el tribunal se pregunta si una nueva situación originaría un deber de cuidado o si debiese invalidar un precedente consolidado que desconoce un deber de cuidado ${ }^{132}$, aquel ha permitido a los tribunales adoptar una postura mucho más amplia y unitaria respecto de la responsabilidad derivada del ilícito de negligencia.

Dos ejemplos adicionales del uso de principios por los jueces ingleses ${ }^{133}$. El primero concierne el enriquecimiento sin causa, cuya singularidad en el Derecho inglés ha sido admitida hace relativamente poco tiempo ${ }^{134}$. Así, en la importante sentencia dictada en Kleinwort Benson Ltd. v. Lincoln City Council135, la Cámara de los Lores declaró que una persona que pagaba por error de derecho en general estaba facultada para repetir,

129 "La regla de que usted debe amar a su vecino deviene en el derecho en que usted no debe dañar a su vecino; y la pregunta del jurista ¿quién es mi vecino? tiene una respuesta restringida. Usted debe adoptar un cuidado razonable para evitar actos u omisiones que razonablemente puede prever dañarían a su vecino. ¿Quién es, entonces, jurídicamente mi vecino? La respuesta parece ser personas que son afectadas tan próxima y directamente por mi acto que debiera razonablemente haber contemplado serían afectadas al dirigir mi pensamiento a los actos u omisiones correspondientes" ((1932) AC 562, p. 580).

130 (1932) AC 562, p. 577.

131 Vg. Rimmer v. Liverpool City Council (1985) QB 1 que de hecho fue más allá, pues la Corte de Apelaciones distinguió un fallo anterior de la Cámara de los Lores en Cavalier v. Pope (1906) AC 428 que había resuelto que un terrateniente no tenía un deber de cuidado en el ilícito de negligencia hacia sus arrendatarios, lo que no impedía que este fuese responsable como constructor y diseñador de las instalaciones atendido el vigor del "principio del vecino", de este modo permitiendo que la regla establecida en Cavalier v. Pope se mantuviese "estrechamente confinada": (1985) QB 1, p. 9.

132 La postura actual se aprecia por lo general en el examen "triple" de Lord Bridge en Caparo Industries plc v. Dickman (1990) 2 AC 605, pp. 617-618, cuyo tercer elemento es la muy abierta cuestión de si es "equitativo, justo y razonable" atribuir responsabilidad por negligencia en el caso concreto.

133 Otros ejemplos pueden hallarse en el "amplio principio de asunción de responsabilidad" en Hedley Byrne v. Heller, interpretado por Lord Goff en Henderson v. Merrett Syndicates Ltd. (1995) 2 AC 145, y en el principio "común" de conocimiento presunto aplicado extraordinariamente, en el contexto de fiadores no comerciales, en Barclays Bank plc v. O'Brien (1994) 1 AC $180 \mathrm{y}$ en Royal Bank of Scotland v. Etridge (No. 2) (2001) UKHL 14; (2002) 1 WLR 1397.

${ }^{134}$ De hecho, los avances más significativos en este ámbito han sido la publicación de trabajos académicos, primero GOFF y JONES (1966) y, posteriormente, la obra del fallecido profesor Peter Birks, An Introduction to the Law of Restitution: BIRKS (1985).

135 (1999) 2 AC 349. 
por exigirlo el principio que proscribe el enriquecimiento injusto (no obstante haber un precedente adverso ${ }^{136}$. Interesantemente, también se suscitó la duda de si una persona que pagaba fundándose en la interpretación judicial del Derecho a esa fecha, pero que después queda sin efecto, constituye un "error" para este fin. La mayoría de la Cámara de los Lores estimó que el hecho de que una sentencia posterior operara retroactivamente implicaba que el pago anterior había sido erróneo ${ }^{137}$, mientras que la minoría consideró que a pesar de que se había modificado el Derecho, esto no podía transformar en erróneo el pago efectuado con antelación porque "la retroactividad no puede falsificar la historia"138. Según Lord Browne-Wilkinson (en la minoría):

La postura teórica ha sido que los jueces no hacen o modifican el Derecho: ellos descubren y declaran el Derecho, que es siempre el mismo. De acuerdo a esta teoría, cuando una decisión anterior es anulada el Derecho no es alterado: su verdadera naturaleza es desvelada, habiendo existido en esa forma desde siempre. Esta posición doctrinaria es, como Lord Reid afirmó en el artículo “The Judge As Law Maker” (1972-1973, 12 J.S.P.T.L. (N.S.) 22), un cuento de hadas en el que nadie continúa creyendo. En verdad, los jueces hacen y cambian el Derecho. La totalidad del Common Law es creación del juez y solo mediante la modificación judicial en el Derecho el Common Law conserva su vigencia en un mundo cambiante ${ }^{139}$.

A su juicio, el carácter retroactivo de las reformas jurídicas judiciales, que se desprende lógicamente del "cuento de hadas", no debiera repercutir en la definición de "error" para los fines de una demanda restitutoria ${ }^{140}$.

El segundo ejemplo se refiere al Derecho que regula la revisión judicial, en donde los tribunales ingleses han sido particularmente activos e innovadores durante los últimos treinta años o más. Al respecto, seleccionaré dos causales legales de revisión del proceso de decisión administrativo: "la arbitrariedad en Wednesbury" y la omisión en atender a las legítimas expectativas de una persona ${ }^{141}$. La primera de estas causales es deducida de la sentencia, de Lord Greene MR en el caso Wednesbury ${ }^{142}$, frecuentemente citada, en la que aceptó que un tribunal podía invalidar una resolución dictada por una autoridad administrativa ejerciendo una facultad legal "si una decisión en una materia de su competencia es tan exorbitante que ninguna autoridad razonable jamás la habría emitido"143. Esta formulación, que para un lego podría lucir excesivamente elaborada, refleja la demarcación de una frontera de trascendencia constitucional. En efecto, el Parlamento ha encomendado al órgano pertinente, y no a los tribunales, el proceso de

136 (1999) 2 AC pp. 357, 363 y, especialmente, p. 373 (por Lord Goff). Este principio había sido reconocido con antelación por la Cámara de los Lores en Lipkin Gorman v. Karpnale Ltd. (1991) 2 AC 548, pp. 558, 568 y 580 (que además reconoció la defensa general de cambio de posición).

137 (1999) 2 AC 349, p. 357 (así explicado por la minoría).

138 (1999) 2 AC p. 358 (por Lord Browne-Wilkinson).

139 (1999) 2 AC p. 358 (por Lord Browne-Wilkinson).

140 (1999) 2 AC pp. 359-360. La retroactividad del proceso judicial de creación jurídica fue una de las razones que condujo a su rechazo por DWORKIN (1977) pp. 84-85.

141 Para explicaciones de su evolución, véase CraIG (2003) Caps. 18-19.

142 Associated Picture Houses Ltd. v. Wednesbury Corpn. (1948) 1 KB 223, pp. 228-230.

143 Associated Picture Houses Ltd. v. Wednesbury Corpn. (1948) 1 KB 223, p. 230. 
dictar las resoluciones administrativas. Los jueces ingleses aceptan que esto significa que deben abstenerse de intervenir simplemente porque consideran que la decisión administrativa fue "errónea" o "irracional", pero que sí pueden actuar con propiedad si dicha resolución supera un umbral de irracionalidad capturado por la fórmula Wednesbury pues la misma puede estimarse que excede la facultad legal del que resuelve y, de ese modo, es ultra vires. La fórmula Wednesbury se ha erigido, en palabras de un comentarista académico de vanguardia, en "la principal herramienta utilizada por nuestros tribunales para controlar las decisiones discrecionales que han rebasado los límites de legalidad de la corrección del fin, etc...." aunque "los tribunales han desarrollado el significado sustantivo de irracionalidad" y complementado su utilidad mediante un examen independiente de abuso de poder ${ }^{144}$. Así, desde una perspectiva fundamental de los roles respectivos del Parlamento, del Ejecutivo y de los tribunales, estos últimos han construido una causal muy amplia de revisión judicial de los actos administrativos, la que ha sido objeto de un notable refinamiento judicial ${ }^{145}$. En segundo lugar, en 2001 el Derecho administrativo inglés acogió sin ambages el principio de la protección de las expectativas legítimas "sustantivas" de los ciudadanos ${ }^{146}$, valiéndose en gran medida del principio tal como está consagrado en el Derecho de la UE, mismo que deriva considerablemente del Derecho alemán ${ }^{147}$. Ambos principios (que pueden relacionarse mutuamente) revisten suma importancia en el Derecho moderno de la revisión judicial, pero su autoridad reposa en fallos judiciales y no en declaraciones legislativas.

\subsection{FORJANDO EXCEPCIONES A PRINCIPIOS JURÍDICOS - ALGUNAS VECES CON REMISIÓN A PRINCIPIO}

Otro tipo de creatividad judicial constituye lo opuesto a este reconocimiento judicial de los principios: la fabricación de excepciones a principios básicos. Desde luego, esto es mucho más fácil de conciliar con la doctrina formal del precedente porque usualmente toma como su punto de partida la distinción de un litigio anterior, aparentemente obligatorio, que contiene la proposición jurídica general. Al respecto, considero que pueden observarse dos clases de técnica: el reconocimiento de una excepción directa (justificada por las circunstancias especiales en el caso anterior o en el caso actual) y de una excepción indirecta o elusión, bajo la cual el proceso previo es declarado inaplicable pues el presente caso es redefinido de forma distinta.

Un ejemplo de las dificultades que la primera técnica genera ocasionalmente puede observarse en el Derecho que regula la "consideration" necesaria para sustentar un convenio que modifica un contrato anterior entre idénticas partes ${ }^{148}$. Por un par de

\footnotetext{
144 CRAIG (2003) p. 612.

145 Craig (2003) Cap. 18 pássim.

146 Sobre esto, CRAIG (2003) Cap. 19. La sentencia señera fue pronunciada por la Corte de Apelaciones en $R$ v. North and East Devon Health Authority Ex p. Coughlan (2001) QB 213, la que originó abundante jurisprudencia.

147 FORSYTH (1988), especialmente pp. 241-244.

148 Sobre las normas generales que reglamentan el requisito de la consideration en el Derecho inglés, véase TREITEL (2003) Cap. 3.
} 
siglos, la posición pareció segura: el cumplimiento de una obligación actual emanada de un contracto para con la otra parte del mismo no constituía una consideration válida para sostener una promesa ${ }^{149}$. Así, en el clásico caso Stilk v. Myrick, resuelto en 1809, unos marineros que habían acordado pilotar un barco para una travesía a una tarifa específica no pudieron obtener como indemnización la cantidad adicional que les había sido prometida cuando se encontraban en la mitad del periplo ${ }^{150}$. Sin embargo, en 1990, en el juicio Williams v. Roffey Bros \& Nicholls (Contractors) Ltd., en el contexto de una promesa hecha por el mandante a un constructor de pagarle una suma adicional por el trabajo de edificación encomendado, como incentivo para que estuviera terminado a tiempo, la Corte de Apelaciones declaró que la promesa de cumplir una obligación actual bajo un contrato para con la otra parte podía constituir una consideration válida si reportaba un "beneficio práctico" al acreedor (como se determinó había sucedido concretamente ${ }^{151}$. No obstante que la Corte de Apelaciones se fundó en el precedente sentado por el Privy Council en Pao On v. Lau Liu Long en la situación análoga (aunque distinguible) de una promesa de cumplir una obligación adeudada a un tercero en virtud de un contrato ${ }^{152}$, el motivo principal de esta sentencia fue expuesto por Glidewell $\mathrm{LJ}^{153}$, quien expresó que "en la actualidad los tribunales debieran estar más preparados para encontrar (la consideration) de manera de reflejar la intención de las partes del contrato cuando los poderes de negociación no son desiguales y el descubrimiento de la consideration hace patente el verdadero propósito de las partes" ${ }^{154}$. Para arribar a esta conclusión, la Corte de Apelaciones no anuló sino que distinguió Stilk v. Myrick fundándose en que: (i) la política de dar eficacia a la intención de las partes había evolucionado considerablemente desde esta sentencia ${ }^{155}$; (ii) la preocupación por proteger a un contratante de la coacción podía ser tratada mediante las normas respectivas, las que no existían -en su versión moderna- a la época del fallo156; y (iii) Stilk había sido decidido en la forma mencionada debido al ambiente histórico ("los rigores de la vida del navegante durante las guerras napoleónicas") ${ }^{157}$.

Sin embargo, enseguida surgieron complejos interrogantes sobre qué constituía realmente un "beneficio práctico" para estos efectos y cuál alcance cabía dar al novel criterio seguido en Williams, habida cuenta que Stilk v. Myrick no había sido anulado

\footnotetext{
${ }^{149}$ Esto puede notarse en el claro recuento del Derecho en esta materia en GUEST (1989) párrs. 197-198 (por Treitel), no obstante que Chitty aceptó que este Derecho es "díficil de conciliar por razones de principio y política con las diversas normas ahora establecidas en las que el deber surge de un contrato con un tercero' (pár. 198). En un párrafo posterior (párr. 202), Chitty remarcó que el principal fallo reciente sobre este último aspecto es el dictado en Pao On v. Lau Liu Long (1980) AC 614 (sentencia del Privy Council).

150 (1809) 2 Camp. 317.

151 Williams v. Roffey Bros \& Nicholls (Contractors) Ltd. (1991) 1 QB 1.

152 Pao On v. Lau Liu Long (1980) AC 614; (1991) 1 QB 1.

153 Con quien concordaron Purchas LJ y Russell LJ.

${ }^{154}$ Purchas LJ y Russell LJ p. 18.

155 Purchas LJ y Russell LJ pp. 14-15, donde Glidewell LJ consideró las observaciones de Lord Scarman ((1980) AC 614, pp. 634-635) como "de aplicación general".

156 (1980) AC 614 pp. 13-14.

157 (1980) AC 614 p. 16.
} 
formalmente. La sentencia posterior de la Corte de Apelaciones en Re Selectmove Ltd. reviste particular interés por el empleo del precedente ${ }^{158}$. En este caso, el problema planteado fue si un pacto por el cual se había aceptado una suma menor como liberación total de una deuda actual entre las partes, podía ser exigido en razón de proporcionar un beneficio práctico al deudor. La Corte de Apelaciones rechazó unánimemente esta posibilidad, dado que la Cámara de los Lores había resuelto (también unánimemente) lo contrario más de un siglo atrás en Foakes $v$. Beer, a pesar de reconocer en esa época el peso del argumento concerniente al beneficio práctico ${ }^{159}$. Adicionalmente, Foakes $v$. Beer había "sido seguido y aplicado en numerosos casos posteriores" ${ }^{160}$. Aunque la Corte de Apelaciones en Re Selectmove Ltd. pudo ver que el enfoque fijado en el caso William podía igualmente extenderse a las promesas de aceptar una cantidad inferior (los hechos ante sí) y a las de pagar un importe adicional (como el propio caso William) ${ }^{161}$, para Peter Gibson LJ (con quien Stuart-Smith LJ y Balcombe LJ coincidieron) resultaba: imposible, siendo coherente con la doctrina del precedente, extender (por la Corte de Apelaciones) el principio del caso Williams a cualesquiera de las circunstancias regidas por el principio de Foakes $v$. Beer... Si tal extensión fuese necesaria, correspondería efectuarla a la Cámara de los Lores o, quizá incluso con mayor propiedad, al Parlamento, tras el estudio de la Comisión Jurídica ${ }^{162}$.

¿Qué consecuencias reviste esto para el mismo caso Williams? Su estatus parece un tanto vulnerable, pero no obstante en sus hechos (comoquiera que sean definidos) ${ }^{163}$ continúa obligando a la Corte de Apelaciones y a los tribunales de inferior jerarquía. Concretamente, ha sido seguido por la Corte de Apelaciones ${ }^{164}$ y por tribunales de primera instancia ${ }^{165}$. Sin embargo, los tribunales en ocasiones lo han aplicado con renuencia, como por ejemplo Colman J., quien ha indicado: Si no fuera por el hecho de que Williams v. Roffey Bros fue una sentencia de la Corte de Apelaciones, no la habría seguido. Esta resolución contradice una norma establecida hace mucho tiempo, con arreglo a la cual la consideration, siendo el precio de la promesa reclamada, debe provenir del acreedor ${ }^{166}$.

Asimismo, una pieza adicional del rompecabezas jurisprudencial gobierna esta especie de casos. Pues, como la Corte de Apelaciones se percató en Re Selectmove Ltd. ${ }^{167}$, los tribunales ya han aceptado una doctrina equitativa que restringe significativa pero parcialmente la decisión alcanzada en Foakes $v$. Beer sobre la doctrina de la consideration $y$, consecuentemente, sobre la exigibilidad de las obligaciones por medio del mismo

\footnotetext{
158 (1995) 1 WLR 474 (si bien la resolución fue dictada en 1993).

159 (1884) 9 App.Cas. 605, especialmente p. 622 (por Lord Blackburn); (1995) 1 WLR 474, p. 479.

160 (1995) 1 WLR 474 p. 480.

161 (1995) 1 WLR 474 pp. 480-481.

162 (1995) 1 WLR 474 p. 481.

163 Por ejemplo, ¿qué elementos constituyeron concretamente el "beneficio práctico"? McKendrick identifica cinco factores, tres de los cuales estima controversiales: MCKENDRICK (2007) pp. 98-100.

164 Gribbon v. Lutton (2001) EWCA Civ. 81.

165 Simon Container Machinery Ltd. v. Emba Machinery A.B (1998) 2 Lloyd's Rep. 429.

166 South Caribbean Trading Ltd. v. Trafigura Beheer BV (2004) EWHC 2676 párr. 108; (2005) 1 Lloyd's Rep. 128.
} 
contrato. Esta es la doctrina del estoppel en la promesa o estoppel en "equidad" (a veces denominada "tolerancia en equidad"), conforme a la cual una persona que se obliga a aceptar una suma inferior como pago total de la deuda está impedida (estopped) de insistir en la promesa original si (i) el deudor confió en la aceptación del acreedor y (ii) ello resulta equitativo en las circunstancias ${ }^{168}$. Sin embargo, a nivel formal, esta teoría equitativa no hace excepción a la doctrina de la consideration como fue reconocida en Foakes $v$. Beer, ya que la promesa no deviene contractualmente obligatoria; a la inversa, esta puede ser eludida en ciertos casos.

Esto me conduce directamente a la segunda forma en que los tribunales ingleses han atenuado el impacto de un precedente e incluso de un principio con el que no están cómodos o no siempre lo están: la elusión de un precedente mediante su redefinición. El ejemplo más obvio de este fenómeno debe encontrarse en el modo en que los tribunales ingleses recurrían a una diversidad de técnicas para evitar el claro precepto que prohíbe a las partes de un contrato conferir un derecho contractual a un tercero, el que fue interpretado como exteriorización del principio del efecto relativo de los contratos y del requerimiento de que la "consideration" debe emanar del acreedor ${ }^{169}$. Este principio fue mantenido firmemente por los tribunales, aunque frecuentemente con evidente repugnancia y convocando al Parlamento a revisar esta materia ${ }^{170}$, llamado que finalmente fue contestado a través de la promulgación de la Ley sobre Contratos (Derechos de los Terceros) de 1999. No obstante, con anterioridad a esta ley, existió un largo listado de posibles excusas: la ampliación de la responsabilidad derivada del ilícito de negligencia, el descubrimiento de "fideicomisos de la promesa", la manipulación del mandato, la cesión, los "contratos subsidiarios" y la creación de acciones en el acreedor en beneficio del tercero ${ }^{171}$. En realidad, aunque la ley de 1999 no derogó formalmente ninguna de estas elaboraciones del Common Law, la Comisión Jurídica -en cuyo trabajo se fundó ese cuerpo legal- aseveró que "la reforma permitirá prevenir la artificialidad y algo de la

167 El estoppel no fue aplicado en los hechos de Re Selectmove porque a la promesa le faltaba la autoridad del órgano público en cuya representación se alegó había sido hecha y que, en las circunstancias, no resultaba inicuo mantenerla: (1995) 1 WLR 474, 481.

168 Central London Property Trust Ltd. v. High Trees House Ltd. (1947) KB 130; D \& C Builders v. Rees (1965) 3 All ER 837.

169 Tweddle v. Atkinson (1861) 1 B \& S 393; Dunlop Pneumatic Tyre Co Ltd. v. Selfridge \& Co. Ltd. (1915) AC 847. Otro ejemplo de esta clase de excepción puede identificarse en A.-G. v. Blake (2001) 1 AC 268, en que la Cámara de los Lores aceptó que, si bien en general las demandas de indemnización de perjuicios por incumplimiento contractual se fundaban normalmente en el daño causado al actor más que en una ganancia obtenida por el demandado, en situaciones "excepcionales" (tal como la planteada en ese caso, a saber una demanda por las utilidades que arrojó la publicación de un libro infringiéndose la obligación asumida por su autor -como un espía que se convirtió en traidor- de no revelar información confidencial) un tribunal podía decretar que se practicara una "cuenta de las ganancias" obtenidas por el contratante incumplidor a expensas del demandante, dando aplicación al principio de restitución (el que prohíbe el enriquecimiento injusto).

${ }^{170}$ Vg. Woodar Investment Development Ltd. v. Wimpey Construction Ltd. (1980) 1 WLR 277, p. 301 (Lord Scarman); p. 291 (Lord Salmon, en su voto disidente, declaró que, sin la intervención del legislador, la Cámara de los Lores habría reconsiderado el punto).

${ }^{171}$ La Comisión Jurídica agrupó convenientemente estas excusas en su informe "Privity of Contract: Contracts for the Benefit of Third Parties" (1996) Law Com N² 242, párrs. 2.8-2.51. 
complejidad"172. Lo interesante acerca de este ejemplo de actividad judicial inglesa es que demuestra tanto una disposición para innovar como restricciones autoimpuestas en la creatividad. En efecto, si bien los tribunales se sintieron capaces de aceptar este atado de evasiones, se rehusaron a tolerar una excepción manifiesta al principio de la relatividad de los contratos como había sido enunciado en forma autorizada ${ }^{173}$, incluso una excepción que pudiera apelar a la intención de las partes contratantes. Esta resistencia suscitó la siguiente crítica de los destacados comparatistas Zweigert y Kötz (escrita con antelación a la ley de 1999):

Es asombroso con cuanta pertinacia el Derecho inglés todavía se adhiere a la idea de que el ius quaesitum tertio en principio es inadmisible... Una de las normas reconocidas de buen comportamiento judicial en Inglaterra es que los principios abstractos no deben ser establecidos en un caso si trascienden de lo que requieren los hechos concretos del mismo. Con todo, este principio no disuadió a Viscount Haldane en Dunlop v. Selfridge ${ }^{174}$ para establecer como una verdad inexorable, sin siquiera aludir al precedente, la proposición general de que "Solo una persona que es parte de un contrato puede demandar fundándose en él” 175 .

Paradójicamente, sin embargo, en mi opinión la continua oposición judicial a reconocer que los contratantes puedan conferir un derecho a un tercero, obedeció en gran medida a la misma característica destacada por Zweigert y Kötz, esto es, que toda proposición o proposiciones jurídicas que la Cámara de los Lores hubiese enunciado solo podrían ser obligatorias respecto de un contrato futuro si tuviesen relación con los hechos del caso sometido a su conocimiento. En efecto, a pesar de que el principio general que permite a las partes contratantes otorgar derechos a un tercero parece sencillo, tan pronto ese principio ha sido aceptado emerge una serie de problemas accesorios, los cuales no podrían ser resueltos simplemente por alguna sentencia genial de la Cámara de los Lores (aun asumiendo que esta hubiese hablado en forma inequívoca y unánime). Es más, el informe de la Comisión Jurídica ${ }^{176}$ y la naturaleza de la legislación definitiva de 1999 (que consta de un texto de unas dos mil palabras) ilustran precisamente como podría verse que diversos problemas incidentales requieren regulación, al menos desde el punto de vista de los juristas ingleses preocupados de evitar que se genere incerteza jurídica y, por ende, incertidumbre contractual como consecuencia indirecta de la reforma principal. Aunque, para ciertos comentaristas, todavía queda alguna incerteza en la correcta interpretación de las normas ${ }^{177}$, su fuerza obligatoria no está supeditada a ningún conjunto de hechos o entorno jurídico en particular, como posiblemente habría acontecido con cualquier decisión judicial acerca de los problemas en discusión. Por ende, existió un sentimiento compartido de que la legislación era la forma más adecuada de reformar el principio de la relatividad

\footnotetext{
172 (1996) Law Com N²42, párr. 3.6.

173 Tweddle v. Atkinson (1861) 1 B \& S 393; Dunlop Pneumatic Tyre Co Ltd. v. Selfridge \& Co. Ltd. (1915)

AC 847 (Cámara de los Lores).

174 (1915) AC 847, pp. 852-854.

175 ZWEIGERT y KÖTZ (1987) p. 156.

176 ZWEIGERT y KÖTZ (1987) p. 171.

177 En particular, STEVENS (2004).
} 
de los contratos, dado que la intervención judicial no contribuiría sino que conduciría a una situación de gran incertidumbre y, en este contexto, a la consiguiente y posible perturbación de las transacciones presentes y futuras.

\subsection{CREATIVIDAD JUDICIAL, LEGITIMIDAD DEMOCRÁTICA Y PARLAMENTO}

Ya he destacado la tensión que existe entre el rol tradicional de los jueces en el desarrollo del Common Law y su relativa falta de legitimidad democrática para crear Derecho en comparación con el Parlamento. También he reparado en ciertas situaciones en las cuales los jueces han invocado la participación del Parlamento, el que ha reaccionado $^{178}$. Desde luego, siempre que un tribunal avanza en relación a los precedentes vigentes, aun si se trata de un incremento paulatino e incluso más cuando este progreso reconoce algún principio nuevo, el tribunal se expone a la acusación de inmiscuirse en el dominio del Parlamento. De hecho, una de las explicaciones más potentes sobre la naturaleza de la adjudicación en el ámbito del Common Law -la "tesis de los derechos" de Ronald Dworkin- fue motivada especialmente por el deseo de permitir a los jueces evitar que se les reproche que su "originalidad" no es democrática ${ }^{179}$. En este punto, no obstante, ofreceré un ejemplo adicional de una situación que los jueces ingleses consideraron preferible entregar al Parlamento.

Existió una diferencia de opinión judicial en torno a la medida en que los tribunales debían reinterpretar el Derecho a fin de proteger a los consumidores y otras personas de las estipulaciones contractuales abusivas y, en particular, de las cláusulas de exención. Por lo general, se aceptaron dos técnicas: la adopción de un criterio exigente respecto de la incorporación de cláusulas en ausencia de un documento firmado ${ }^{180}$ y la interpretación contra proferentem incluso en un grado artificial ${ }^{181}$. Sin embargo, en dos ocasiones Lord Denning MR intentó ir más allá, declarando que ciertos incumplimientos contractuales eran tan fundamentales que producían la terminación automática del contrato y, con ello, de cualquier cláusula de exención, pese a que esto contradecía abiertamente las opiniones expresadas anteriormente por la Cámara de los Lores ${ }^{182}$. Con

\footnotetext{
178 Supra 1.1, p. 9, circa n. 42 a n. 43.

179 DWORKIN (1977) pp. 84-85.

180 Thornton v. Shoe Lane Parking Ltd. (1971) 2 QB 163; aplicado en Interfoto Picture Library Ltd. $v$. Stiletto Visual Programmes Ltd. (1989) QB 433, p. 438. La postura establecida es que este enfoque no opera en relación a instrumentos suscritos en los que la misma firma satisface el requisito de conocimiento de los términos: L’Estrange v. F. Graucob Ltd. (1934) 2 KB 394.

${ }^{181} \mathrm{Vg}$. Hollier v. Rambler Motors Ltd. (1972) 2 QB 71 (la cláusula que estipulaba que el reparador no era "responsable del daño causado a los automóviles del cliente a consecuencia de un incendio en el local" no era lo suficientemente clara como para excluir la responsabilidad por culpa). Empero, se ha declarado que, tras la institución de controles abiertos por la Ley sobre Cláusulas Contractuales Abusivas de 1977, los tribunales deben evitar introducir distorsiones en la lengua inglesa: Photo Production Ltd. v. Securicor Transport Ltd. (1978) 1 WLR 827, p. 851.

182 Harbutt's 'Plasticine' Ltd. v. Wayne Tank and Pump Co. Ltd. (1970) 1 QB 447; Photo Production Ltd. v. Securicor Transport Ltd. (1978) 1 WLR 827, p. 863 (CA). La sentencia de la Cámara de los Lores recayó en Suisse Atlantique Société d'Armement Maritime S.A. v. N.V. Rotterdamsche Kolen Centrale (1967) 1 AC 361. La Cámara de los Lores recogió esta interpretación sobre su importancia al conocer de Photo Production: (1980) AC 827, 841.
} 
deferencia, el trato que Lord Denning dio a este fallo fue particularmente caballeroso, como el mismo Lord Wilberforce reconoció al señalar que Lord Denning "supuestamente aplicó esta... sentencia... pero en lo concreto dos citas recogidas de dos de los discursos de los Lores"183. Tan pronto la Cámara de los Lores conoció la doctrina del incumplimiento fundamental, la rechazó rotundamente por ser contraria a la autoridad ${ }^{184}$, opuesta a los principios ${ }^{185}$ e innecesaria atendida la intervención parlamentaria en $1977^{186}$. Respecto de lo último, Lord Wilberforce observó que:

Es notable que el Parlamento se haya abstenido de legislar en todo el campo contractual. Tras esta ley, en materias comerciales en general, en las que el poder negociador de las partes no es desigual, y en que los riesgos son soportados normalmente por medio de seguros, no solo no está demostrada la necesidad de intervención judicial, sino que todo indica, y esta parece haber sido la intención del Parlamento, que debe permitirse a las partes la libertad para distribuir los riesgos según lo consideren adecuado y deben respetarse sus decisiones ${ }^{187}$.

De esta manera, la limitada intervención del Parlamento en la ley de 1977 fue vista como una razón para que los tribunales no tomaran parte en la misma área ${ }^{188}$, confiriendo así a la legislación un cierto efecto preventivo en el futuro desarrollo del Common Law.

\subsection{CAMBIANDO LAS PERSPECTIVAS DE POLÍTICA PÚBLICA Y JUSTICIA SOCIAL}

Sin embargo, en algunas oportunidades, la Cámara de los Lores ha explicado abiertamente que el motivo por el cual ha determinado separarse de sus propias resoluciones previas reside en las necesidades cambiantes de la sociedad y/o en las percepciones variables de política pública. Al respecto, daré dos ejemplos contrastantes, tomados del Derecho penal ${ }^{189}$.

183 (1980) AC 827, p. 841.

184 Suisse Atlantique Société d'Armement Maritime S.A. v. N.V. Rotterdamsche Kolen Centrale, ob. cit.

185 El principio es que la "terminación" de un contrato simplemente establece si una o ambas partes están excusadas de su ulterior cumplimiento, sin descartar la responsabilidad por los perjuicios (y, por tanto, no debiera desatenderse las cláusulas sobre daños): (1980) AC 827, p. 844.

186 Ley sobre Cláusulas Contractuales Abusivas de 1977.

187 (1980) AC 827, p. 843.

188 Un enfoque similar se aprecia en Murphy v. Brentwood DC (1991) 1 AC 398 donde la Cámara de los Lores anuló su fallo recaído en Anns v. Merton LBC (1978) AC 728 sobre la existencia de un deber de cuidado en el ilícito de negligencia de una autoridad local para con el dueño de un casa con motivo del ejercicio de sus facultades legales de inspección de los cimientos. Esto fue justificado, en parte, en la tímida intervención parlamentaria a través de la Ley sobre Locales Defectuosos de 1972: (1991) 1 AC 398, pp. 457, 472, 482, 482, 491-492, 498. Sin embargo, se ha señalado que esta no es una razón convincente, ya que el informe de la Comisión Jurídica que sirvió de base a la Ley de 1972 había asumido que el Common Law continuaría evolucionando: STAPLETON (1991) p. 268, citando Comisión Jurídica, "Civil Liability of Vendors for Defective Premises”, Law Com No 40 (1970) (H.C.P. 184), especialmente párrs. 11 y 73.

189 Un ejemplo del todo diferente de la Cámara de los Lores, sosteniendo que el Derecho establecido (en la especie, su propia resolución anterior en Rondel v. Worsley (1969) AC 191) ya no reflejaba la política pública contemporánea, se observa en Arthur JS Hall \& Co. v. Simons (2002) 1 AC 651, en el contexto de 
En primer lugar, en $R v \cdot R$ (sobre violación y excepción marital) ${ }^{190}$ la Cámara de los Lores revisó la norma de Derecho establecida en cuya virtud se presumía que una esposa había consentido irrevocablemente a tener relaciones sexuales con su marido ${ }^{191}$. En la opinión unánime de la Cámara de los Lores, “(e)l Common Law es, con todo, capaz de evolucionar a la luz de los cambiantes desarrollos sociales, económicos y culturales"192, y una de las transformaciones es que el matrimonio, en tiempos modernos, se considera como una asociación entre iguales ${ }^{193}$. Como resultado de esto, la Cámara de los Lores liberó al Common Law de la "absurda" ficción del consentimiento en razón del mismo matrimonio ${ }^{194}$.

Por el contrario, en $C v$. DPP la Cámara de los Lores se negó a modificar las normas sobre capacidad penal de los delincuentes juveniles ${ }^{195}$. A su juicio, y a pesar de que tres Lores admitieron la necesidad de una reforma en este ámbito, la presunción de que un menor entre diez y catorce años era doli incapax y que únicamente podía ser refutada mediante una prueba clara y concluyente de que el menor sabía que su acto era gravemente malo, continuaba integrando el Derecho inglés ${ }^{196}$. En este respecto, Lord Lowry identificó "algunas asistencias a la navegación en un mar 'de legislación judicial' inciertamente dibujado"197:

(1) si la solución es dudosa, los jueces deben tener cuidado de imponer su propio remedio; (2) la cautela debe prevalecer cuando el Parlamento ha desperdiciado las oportunidades de aclarar una dificultad conocida o ha legislado pero sin resolverla; (3) las materias de política social debatidas son áreas menos adecuadas para la intervención judicial que los problemas netamente jurídicos; (4) las doctrinas jurídicas fundamentales no deben ser descartadas livianamente; (5) y los jueces no deben introducir un cambio salvo que puedan lograr irrevocabilidad y certeza ${ }^{198}$.

Evidentemente, estas indicaciones en modo alguno son taxativas ni menos pueden ser consideradas como un conjunto de reglas. Sin embargo, ellas comunican en forma muy clara la idea de precaución con que la Cámara de los Lores siente que debiera embarcarse en un proceso de franca creación jurídica ("legislación judicial”).

una supuesta exención de responsabilidad por negligencia de unos abogados. La mayoría de la Cámara de los Lores fue cuidadosa al indicar que no anulaba su fallo previo por ser incorrecto, sino porque en el mundo de hoy "esa resolución ya no reflejaba correctamente la política pública": (2002) 1 AC 651, p. 683 (por Lord Steyn).

190 (1992) 1 AC 599.

191 Esta regla consolidada fue rastreada hasta Hale (1736) Cap. 58, p. 629, aprobado en $R$. v. Clarence (1888) 22 QBD 23.

192 (1992) 1 AC 599, p. 615.

193 (1992) 1 AC 599, p. 616 (por Lord Keith de Kinkel, con quien los demás jueces coincidieron).

194 (1992) 1 AC 599, p. 615.

195 (1996) AC 1.

196 (1996) AC 1.

197 (1996) AC 1, p. 28.

198 (1996) AC 1. 


\section{LOS JUECES INGLESES Y LA "JURISPRUDENCIA" EUROPEA}

¿Cuál es el trato que los jueces ingleses conceden al Derecho europeo contenido en casos (o "jurisprudencia", término conscientemente no-nativo que se usa regularmente) ${ }^{199}$ y que emana del Tribunal de Justicia de las Comunidades Europeas ("TJCE”) o del Tribunal Europeo de Derechos Humanos ("TEDH")?

\subsection{LOS CRITERIOS JUDICIALES INGLESES RESPECTO DE LA JURISPRUDENCIA DEL TRibunal De Justicia de las COMUNidAdes Europeas}

¿En qué medida los jueces ingleses han transferido su comprensión de la doctrina del precedente al tratamiento que dan a la jurisprudencia del TJCE? Este interesante tema no ha sido objeto de investigación específica, aunque ciertas ideas son relativamente claras.

Los tribunales ingleses han aceptado sólida y completamente el principio de la supremacía del Derecho de la UE y, por tanto, la preeminente autoridad interpretativa del TJCE ${ }^{200}$. Según May LJ indicó recientemente, "el tribunal está obligado a seguir y no meramente a tomar en cuenta la jurisprudencia del Tribunal de Justicia de las Comunidades Europeas con arreglo al artículo 2 de la Ley sobre Comunidades Europeas de 1972"201. Sin embargo, estos escuetos enunciados no hacen justicia al grado en que los jueces ingleses han adherido a una "visión interna" del Derecho de la UE, tanto en términos de su legislación como de la jurisprudencia del TJCE pues, al interpretar el Derecho de la UE, los tribunales ingleses han aceptado totalmente la necesidad de acatar los principios y las prácticas interpretativas europeas. Por cierto, los tribunales ingleses pueden remitir al TJCE toda duda de interpretación y tienen la obligación de hacerlo bajo ciertas circunstancias ${ }^{202}$, pero fuera de ello respetan la forma en que el TJCE interpreta el Derecho de la UE con motivo de su propio análisis. Aquí existen cuatro elementos sobresalientes.

Primero, los tribunales ingleses aluden a las finalidades de las normas europeas con ocasión de su interpretación, revisando los considerandos de las directivas y pregun-

\footnotetext{
199 Este es, claramente, un anglicismo del término francés la jurisprudence, recogido por primera vez en los círculos jurídicos ingleses siguiendo la práctica del Tribunal de Justicia de las Comunidades Europeas. En el concierto inglés la palabra "jurisprudencia" tiene además otras dos acepciones, a saber: el conocimiento jurídico general (como en la denominación formal del grado académico que la Universidad de Oxford otorga al Licenciado en Derecho: el Honour School of Jurisprudence) y la teoría y filosofía jurídicas (vg. los "Ensayos sobre Jurisprudencia de Oxford", una serie de trabajos coleccionados en esta área).

${ }^{200}$ R. v. Secretary of State for Transport Ex p. Factortame Ltd. (No 2) (1991) 1 AC 603, especialmente pp. 658-659 (por Lord Bridge), donde la Cámara de los Lores dejó de aplicar una norma legal nacional con el fin de adecuarse a la interpretación del Derecho de la UE por el TJCE. Sin embargo, como Craig y De Búrca observan, "(l)a aceptación de la supremacía del Derecho comunitario en el Reino Unido no ha estado exenta de dificultades": véase CRAIG y DE BÚRCA (2003) pp. 301-312.

${ }^{201}$ Countryside Alliance and others v. A.-G. (2005) EWHC 1677 (Admin) párr. 316, resolviendo a favor del Tribunal Divisional y distinguiendo al respecto la jurisprudencia del Tribunal Europeo de Derechos Humanos, infra 4.2, p. 38, circa n. 213.

202 Art. 234 Tratado Constitutivo de la CE.
} 
tándose si una interpretación en particular promovería o no los objetivos declarados en las mismas ${ }^{203}$.

Segundo, respecto de las directivas de la CE, los tribunales ingleses frecuentemente han trascendido la legislación del Reino Unido que las implementa y examinado las palabras y el significado de la directiva en sí, considerando a esta como el "texto dominante" 204 . De este modo, los tribunales han aceptado los argumentos de que una o más versiones idiomáticas de una directiva, diversas del inglés, sugieren una determinada interpretación, ${ }^{205}$ dando así eficacia al principio de la idéntica autoridad de las diversas versiones idiomáticas reconocidas por el TJCE ${ }^{206}$.

Tercero, los tribunales ingleses se refieren a los principios generales del Derecho de la CE en sus propias interpretaciones de normas particulares de la UE, por ejemplo, el principio de la efectividad ${ }^{207}$ o el principio de la proporcionalidad ${ }^{208}$. De este modo, los tribunales están aplicando el criterio general de interpretación del TJCE, el cual no se encuentra en un caso, sino que en su jurisprudencia como un todo. En ausencia de un fallo del TJCE (en algunas áreas jurídicas la jurisprudencia europea es particularmente escasa), los tribunales ingleses toman una postura basada en la predicción, tratando de decidir como el TJCE hubiese resuelto si se hubiese requerido su intervención.

Cuarto, donde existe jurisprudencia relevante del TJCE, los jueces ingleses se adhieren a las proposiciones jurídicas expuestas por este, reputándola una fuente de

${ }^{203}$ Ejemplos actuales se encuentran en: Mathews v. Kent and Medway Towns Fire Authority (2006) UKHL 6 párrs. 24-25, 36 (2006); 2 All ER 171 (en el contexto de la Directiva 97/81/CE relativa al acuerdo marco sobre el trabajo a tiempo parcial concluido por la UNICE, el CEEP y la CES); Bowman v. Fels (2005) EWCA Civ 226 párrs. 41-44, 53 (2005); 4 A11 ER 609 (en relación a la Directiva 91/308/CEE, modificada por Directiva 2001/97/CE, modificada por Directiva 2001/97/CE, relativa a la prevención de la utilización del sistema financiero para el blanqueo de capitales).

${ }^{204}$ Vg. Director General of Fair Trading v. First National Bank (2001) UKHL 52 párr. 31 (2002); 1 AC 481 (por Lord Steyn); A v. National Blood Authority (2001) 3 All ER 289 párr. 2 donde Burton J aludió a la directiva en cuestión como "la fuente", sin comprometerse con la legislación nacional para la implementación de aquella.

205 Un ejemplo llamativo reciente puede verse en London Borough of Newham v. Khatun (2004) EWCA Civ 55 párrs. 78-83 (2005); QB 37 donde la Corte de Apelaciones sostuvo que la Directiva 93/13/CEE sobre las cláusulas abusivas en los contratos celebrados con consumidores, tiene aplicación en los contratos de arrendamiento pese a que la versión inglesa de la directiva habla de los "vendedores o proveedores" de "bienes" con referencia a la versión francesa y a otras versiones, las cuales emplean la terminología adecuada para los "vendedores o proveedores" de "propiedad" en general.

${ }^{206}$ El principio de igualdad lingüística o de multilingüismo fue establecido, al fundarse la UE, por el Reglamento $\mathrm{N}^{\circ} 1$ de 1958, el que determina los idiomas que la Comunidad Económica Europea debe utilizar: DO 1958 17/385.

207 Un ejemplo particularmente notable se halla en Autologic Holdings plc v. IRC (2005) UKHL 54 párrs. 30, 38, 91-96 (2006); 1 AC 118 (relativo a la jurisdicción nacional apropiada para conocer de demandas deducidas en contra de la autoridad tributaria nacional que involucran supuestas infracciones del Derecho de la CE).

${ }^{208}$ Por ejemplo, la prohibición de circulación en el extranjero de los hooligans (hinchas de fútbol) fue examinada con referencia al principio comunitario de la proporcionalidad en Gough v. Chief Constable (2002) EWCA Civ 351 (2002); 2 All ER 985 párrs. 62, 84-85 (respecto de la Directiva 73/148/CEE, relativa a la supresión de las restricciones al desplazamiento y a la estancia, dentro de la Comunidad, de los nacionales de los Estados Miembros en materia de establecimiento y de prestación de servicios, Art. 2). 
interpretación autorizada del Derecho de la UE pertinente. Sin embargo, cuando una sentencia del TJCE no es claramente concluyente acerca de la cuestión jurídica planteada ante el tribunal inglés, los jueces ingleses cuidan de revisar la jurisprudencia relevante o análoga y seguir los argumentos de fondo descubiertos en las sentencias del TJCE y en las opiniones de sus abogados generales. Al respecto, es notable que los abogados litigantes ingleses exhiben gran disposición para utilizar (y a veces citar) doctrina del Derecho europeo en cuestión, incluso escrita en un idioma diferente del inglés ${ }^{209}$.

Sin embargo, existen dos aspectos del tratamiento de la doctrina del precedente en Inglaterra que no aparecen o que no están presentes del mismo modo en el trato inglés de la jurisprudencia del TJCE.

Primero, no existe la misma relación formal entre los hechos de un juicio europeo y la fuerza de autoridad de las proposiciones que el TJCE declara en comparación a la que se halla en el concepto inglés de ratio decidendi, motivo por el cual no existe una ocasión para "distinguir" las sentencias del TJCE de la manera que se aprecia en el contexto nacional estrictamente inglés. Aquí, por cierto, reviste particular importancia la forma en que se presenta un problema jurídico al TJCE, pues si es incoado por la Comisión en procedimientos por infracción tramitados contra el Reino Unido u otro Estado Miembro conforme al artículo 226 del Tratado constitutivo de la CE, el asunto es necesariamente abstracto pues, por definición, no existe litigación nacional ni, por ende, hechos que originen problema alguno. Con todo, incluso cuando un pleito es remitido al TJCE para su interpretación autoritativa bajo el artículo 234 del Tratado constitutivo de la CE y, por tanto, aquel posee un antecedente fáctico, el TJCE tiende a veces a tratar la o las dudas jurídicas levantadas como cuestiones abstractas que recién se han suscitado en este u otro entorno fáctico. Así, el contexto jurídico del problema (por ejemplo, la respectiva regulación o directiva de la CE) es crucial para su solución, pero el ambiente fáctico puede ser conservado un tanto como antecedente, estimándose arquetípicamente que el tribunal nacional debe resolverlo: el TJCE explica los problemas jurídicos pertinentes que el tribunal nacional debe zanjar en relación a los hechos ventilados ante este, pero se rehúsa a sacar conclusiones sobre la importancia que tales problemas tiene respecto de los hechos alegados ante el tribunal nacional ${ }^{210}$. Sin embargo, esta no es en absoluto una tendencia universal, puesto que en otras situaciones el TJCE prefiere más bien mantener un mayor control sobre el proceso de toma de decisiones doméstico, dando claras indicaciones al tribunal nacional que ha referido la cuestión sobre la forma en que debiera aplicar el Derecho de la CE a los hechos de que

209 Vg. A. v. National Blood Authority (2001) 3 All ER 289 párrs. 31, 34, 39, 45-46 en donde se cita el trabajo de académicos alemanes, italianos y españoles (aparentemente traducido en forma especial para este litigio).

210 Pueden ofrecerse tres ejemplos: la evaluación de las "cláusulas abusivas" bajo la Directiva 93/13/CEE sobre las cláusulas abusivas en los contratos celebrados con consumidores, en Freiburger Kommunalbauten GmbH Baugesellschaft \& Co. KG v. Hofstetter, Caso C-237/02 de 1 de abril de 2004; las palabras "daño" y "poniendo en circulación" para los efectos de la Directiva 85/374/CEE, sobre responsabilidad por los daños causados por productos defectuosos, en Veedfald v. Arhus Amtskommune, Caso C-203/99 (2001), ECR 1-3569, y en O'Byrne v. Sanofi Pasteur SA, Caso C-127/04 de 9 de febrero de 2006, respectivamente. 
conoce $^{211}$. Todo esto significa que en la medida en que los hechos "ante" el TJCE integran genuinamente el contexto de las proposiciones de Derecho en sus sentencias depende del grado en que el TJCE escoge hacerse cargo de los hechos. Por otra parte, aunque pudiera pensarse que un juez inglés u otro jurista tendería a ser más sensible respecto tanto del contexto fáctico como jurídico de las decisiones del TJCE (las que forman efectivamente un elemento significativo en su discusión), no creo que considerarían apropiado importar a su análisis acerca de la trascendencia de la jurisprudencia europea la distinción técnica entre ratio decidendi y obiter dictum con la que están familiarizados en el concierto nacional: primero, porque ellos estimarían que esto es parte de una doctrina del precedente más amplia peculiar al Derecho inglés y, segundo, por cuanto en su aproximación al Derecho de la UE, ellos tratan de imitar la forma en que el mismo TJCE resolvería el caso y este distingo técnico parece no pertenecer al criterio que el TJCE adopta para con su propia jurisprudencia ${ }^{212}$.

\subsection{LOS CRITERIOS JUDICIALES INGLESES RESPECTO DE LA JURISPRUDENCIA Del Tribunal Europeo de Derechos Humanos}

La postura formal de la jurisprudencia del TEDH ha cambiado significativamente en el Reino Unido luego de "traer a casa" las proposiciones (o su mayor parte) contenidas en el mismo Convenio Europeo sobre Derechos Humanos y Libertades Fundamentales (el "Convenio Europeo"), en virtud de la Ley sobre Derechos Humanos de 1998 (la "ley de 1998”). Previo a esta ley, aunque el Reino Unido era un signatario del Convenio Europeo, sus normas no integraban, sin más, las leyes domésticas de este, atendido el enfoque generalmente dualista del Reino Unido hacia los tratados internacionales. Pese a esta posición, los tribunales ingleses buscaron interpretar las leyes o el Common Law de una manera compatible con el Convenio Europeo ${ }^{213}$. Sin embargo, con la entrada en vigencia de la ley de 1998, los tribunales ingleses están obligados a conocer de asuntos concernientes a los derechos de una persona bajo el Convenio Europeo ${ }^{214}$. pero de diversas formas según si el recurrente que alega fundarse en este lo hace con referencia a una Ley del Parlamento (la cual, a lo sumo, puede ser declarada "incompatible" con un derecho consagrado en el Convenio Europeo y, por tanto, susceptible de ser corregida por el Parlamento mediante un procedimiento especial $^{215}$ ), a una legislación secundaria, al Common Law o a decisiones de órganos públicos u órganos privados que "actúan públicamente" 216 . Sobre el particular, es interesante que la ley

\footnotetext{
211 Vg. Köbler v. Austria Caso C-224/01 (2003) I-10239, en el cual el TJCE declaró (párr. 54) que el tribunal nacional debe tomar en cuenta una serie de factores al determinar si el Derecho de la UE exige atribuir responsabilidad al Estado por omitir su aplicación, pero luego dio muy claras indicaciones de la forma en que consideró que el tribunal austríaco debía utilizar dichos factores en la situación planteada ante el mismo: párrs. 70 y ss.

212 BROWN y JACOBS (1989) p. 312. Cf. las opiniones manifestadas por MACKENZIE STUART y WARNER (1981) p. 276, discutidas por BARCELÓ (1997) p. 407, párrs. 415-416.

213 LESTER (2000) pp. 88, 96-97.

${ }^{214}$ La Ley de 1998 incorpora la mayoría de los derechos promulgados por el Convenio Europeo y sus protocolos en el Derecho doméstico del Reino Unido: Ley de 1998, art. 1, anexo 1.

215 Ley sobre Derechos Humanos de 1998, arts. 4 y 10.

${ }^{216}$ Ley sobre Derechos Humanos de 1998, art. 6.
} 
de 1998 contemple una norma explícita y cuidadosa acerca de la función que cumple la jurisprudencia del TEDH. El Artículo 2(1) dispone que:

Una corte o tribunal que resuelve un problema que ha surgido en relación a un derecho en el Convenio debe tomar en cuenta toda... sentencia, decisión, declaración u opinión consultiva del Tribunal Europeo de Derechos Humanos... dondequiera que haya sido emitida o dada, en la medida que, a juicio de la corte o tribunal, sea relevante para el proceso en que dicho problema se ha suscitado ${ }^{217}$.

En consecuencia, esta norma reduce la importancia de las resoluciones del TEDH, en relación a los fallos emanados de tribunales del Reino Unido, a un deber del tribunal nacional de "tomar en cuenta" toda sentencia o decisión pronunciada por el Tribunal de Estrasburgo. Tal como Lord Bingham de Cornhill ha aseverado con autoridad en $R$ (Ullah) v. Special Adjudicator:

Pese a que dicha jurisprudencia no es estrictamente obligatoria, se ha sostenido que los tribunales, en ausencia de ciertas circunstancias especiales, deben seguir toda jurisprudencia clara y constante del tribunal de Estrasburgo... ${ }^{218}$ Esto refleja el hecho de que el Convenio es un instrumento internacional, cuya correcta interpretación solo puede ser expuesta con autoridad por el tribunal de Estrasburgo. De esto se desprende que un tribunal nacional sujeto a un deber como el que el artículo 2 impone no debiera, sin una razón de peso, atenuar o debilitar el efecto de la jurisprudencia de Estrasburgo... Desde luego, los Estados Miembros pueden reconocer derechos más generosos que los que garantiza el Convenio, pero tal provisión no debe ser el producto de la interpretación del Convenio por los tribunales nacionales, ya que el significado del Convenio debe ser uniforme en todos los Estados parte del mismo. El deber de los tribunales nacionales es mantener el ritmo con la jurisprudencia de Estrasburgo conforme esta evoluciona en el tiempo: no más, pero ciertamente no $\operatorname{menos}^{219}$.

No obstante, se ha agregado que:

(e)n una área en desarrollo, un tribunal doméstico quizá también tiene que considerar si una jurisprudencia relativamente antigua (del TEDH) refleja el resultado que el tribunal aún alcanzaría. El propio Tribunal de Estrasburgo declaró en Goodwin v. United Kingdom ${ }^{22} \ldots$ que, aunque no se desviará sin un motivo válido de los precedentes, "el tribunal debe tener en cuenta las condiciones cambiantes

217 Énfasis agregado. El art. 2(1) prosigue declarando que un tribunal también debe tomar en consideración toda "opinión de la Comisión contenida en un informe adoptado conforme al Artículo 31 del Convenio... decisión de la Comisión en relación al Artículo 26 ó 27(2) de la Convenio, o... decisión del Comité de Ministros bajo el Artículo 46 del Convenio".

$218 R$ (Alconbury Developments Ltd.) v. Secretary of State for the Environment, Transport and the Regions (2001) UKHL 23; (2003) 2 AC 295, párr. 26.

219 (2004) UKHL 26; 2 AC 323 párr. 20 (con quien concurrieron los demás miembros de la Cámara de los Lores) y así descrita por Lord Mance en Secretary of State for Work and Pensions v. M (2006) UKHL 11 párr. 128 (Transcripción Lexis).

220 (2002) 35 EHRR 18, párr. 74. 
en el Estado Demandado y en los Estados Contratantes en general y responder, por ejemplo, ante cualquier convergencia cambiante en relación a los estándares por lograr" 221 .

Por lo tanto, los miembros de la Cámara de los Lores en general -como también otros jueces del Reino Unido- están comprometidos de cerca con la jurisprudencia del TEDH cuando la consideran relevante, pero como el pasaje anterior enfatiza, lo hacen de una forma distintiva, entendiendo su naturaleza internacional y carácter mínimo; en definitiva, sin estar obligados por ella. En un sentido amplio, podría sostenerse que la autoridad tradicional que los juristas ingleses atribuyen a la jurisprudencia afecta la seriedad con que los jueces ingleses tratan y evalúan la jurisprudencia del Convenio Europeo, pero no puede señalarse que simplemente exporten su propia forma de tratar el precedente nacional hacia el ámbito del Convenio Europeo.

Sin embargo, un aspecto final digno de mención, es la relación entre el deber de un tribunal de tomar en cuenta la jurisprudencia del TEDH y su deber de obedecer la jurisprudencia nacional anterior que deriva de la doctrina del precedente. Este problema fue debatido en Leeds City Council v. Price ${ }^{222}$ donde la Cámara de los Lores adujo que, más que justificar que un tribunal nacional acatara la jurisprudencia del TEDH cuando esta era "claramente incoherente" con un precedente nacional, debía seguir la posición nacional en el interés de la certeza jurídica, reservando a la Cámara de los Lores la revisión del precedente a la luz de la jurisprudencia del $\mathrm{TEDH}^{223}$.

\section{CONCLUSIÓN}

Al comienzo de este trabajo cité dos dicta de magistrados de la Cámara de los Lores quienes adoptan, aparentemente, visiones muy diferentes de sus roles en la evolución del Derecho: Lord Bingham pareciendo seguir un criterio más conservador, considerando la adhesión al precedente como la "piedra angular" del sistema inglés, en tanto que Lord Browne-Wilkinson reconociendo abiertamente que el propio Common Law es hecho por el juez y que este debe reformarlo para mantener su vigencia en el mundo moderno. Sin embargo, respetuosamente, sus visiones no son incompatibles. Es efectivo que la doctrina inglesa del precedente en realidad presenta ciertas características particulares en el trato de la autoridad atribuida a las causas anteriores, especialmente debido a la singular posición del propio Common Law y al grado en que los juristas ingleses aprecian que esta autoridad está amarrada a los hechos y argumentos expuestos en los

221 Secretary of State for Work and Pensions v. M (2006) UKHL 11 párrs. 128 y 131 (Transcripción Lexis). 222 (2006) UKHL 10; (2006) 2 WLR 570.

223 (2006) 2 WLR 570 párrs. 43-45 (Lord Bingham de Cornhill), con la aprobación de Lord Nicholls (pár. 50), Lord Hope (párr. 62), Lord Scott (párr. 121), Lord Walker (párr. 177), Baronesa Hale (párr. 178) y Lord Brown (párr. 213). Lord Bingham (pár. 45) expuso la posibilidad de una excepción en los casos de "carácter extremo", citando como ejemplo X (Minors) v. Bedfordshire County Council (1995) 2 AC 633, el que la Corte de Apelaciones no siguió en D v. East Berkshire Community NHS Trust (2004) QB 558, procedimiento que no fue criticado por la Cámara de los Lores: (2005) UKHL 23 (2005); 2 AC 373 párrs. $21,30-36,82,119,124-125$. 
litigios previos. Con todo, en múltiples pleitos ingleses -especialmente aquellos ante la Corte de Apelaciones y la Cámara de los Lores- los jueces no procuran simplemente seguir la ratio decidendi de los casos o ser convencidos por el obiter dicta de jueces anteriores. Por el contrario, ellos intentan comprometerse con los diversos enfoques, técnicas, principios y consideraciones descubiertas en los litigios previos y evaluar sus argumentos de fondo. De este modo, el proceso de decisión judicial inglés se revela como mucho más complejo que lo que la descripción formal de la doctrina del precedente sugeriría fácilmente, toda vez que los jueces procuran dirimir la tensión que existe entre las virtudes de la coherencia y la igualdad que subyacen al stare decisis y la necesidad de adaptar el Derecho para hacer justicia a los hechos que evolucionan ante sí.

\section{BIBLIOGRAFÍA CITADA}

BARCELÓ, John (1997): "Precedent in European Community Law", en: MACCORMICK, Neil y Summers, Robert (edits.), Interpreting Precedents: A Comparative Study (Aldershot, Dartmouth Publishing) pp. 407-436.

BEAlE, Hugh (edit.) (2004): Chitty on Contracts (London, Sweet \& Maxwell, 29a ed.) vol. I, $1.866 \mathrm{pp}$.

BELL, John (2000): "Sources of English Law", en: BIRKS, Peter y FELDMAN, David,

English Private Law (Oxford, Oxford University Press) vol. I, pp. 3-43.

BELL, John (2001): French Legal Cultures (London, Butterworths) 276 pp.

Bell, John, Boyron, Sophie y WhitTaker, Simon (1998): Principles of French Law (Oxford, Oxford University Press) 517 pp.

Bentham, Jeremy (1776): A Fragment on Government (Dublin, Sheppard et al.) 132 pp.

BIRKS, Peter (1985): An Introduction to the Law of Restitution (Oxford, Oxford University Press) $455 \mathrm{pp}$.

Blackstone, William (1765): Commentaries on the Law of England (Oxford, Clarendon Press, $1^{\text {a }}$ ed.), libro I, pp. 116-473, disponible en: http://www.yale.edu/lawweb/ avalon/avalon.htm (fecha de consulta: 3 de diciembre de 2007).

Brown, Lionel y JACOBS, Francis (1989): The Court of Justice of the European Communities (London, Sweet \& Maxwell) 3a ed., 343 pp.

CARbonnier, Jean (1990): Droit civil - Introduction (Paris, PUF) $18^{\mathrm{a}}$ ed., $352 \mathrm{pp}$.

Craig, Paul (2003): Administrative Law (London, Sweet \& Maxwell) 5a ed., 960 pp.

Craig, Paul y De BúrCA, Gráinne (2003): EU Law: Text, Cases and Materials (Oxford, Oxford University Press) 3a ed., 1.241 pp.

Cross, Rupert y Harris, James (1991): Precedent in English Law (Oxford, Clarendon Press) $4^{\mathrm{a}}$ ed., $246 \mathrm{pp}$.

Dawson, John (1968): The Oracles of the Law (Connecticut, Greenwood Press) 520 pp. DwOrKIN, Ronald (1977): Taking Rights Seriously (London, Duckworth) 293 pp.

FORSYTH, Christopher (1988): "The Provenance and Protection of Legitimate Expectations", Cambridge Law Journal, vol. 47: pp. 238-260.

Goff, Robert y Jones, Gareth (1966): The Law of Restitution (London, Sweet \& Maxwell) 540 pp. 
Guest, Anthony (edit.) (1989): Chitty on Contracts (London, Sweet \& Maxwell) 26a ed., vol. I, 2.195 pp.

Hale, Sir Matthew (1736): History of the Pleas of the Crown (London, E. y R. Nutt; R. Gosling, por F. Gyles, T. Woodward y C. Davis) vol. I, 710 pp.

HARRIS, Bruce (2002): "Final appellate courts overruling their own 'wrong' precedents: the ongoing search for principle”, Law Quarterly Review, vol. 118: pp. 408-427.

HART, Herbert (1961): The Concept of Law (Oxford, Oxford University Press) 262 pp.

HoldsworTh, Sir William (1926): History of English Law (London, Methuen \& Co.) vol. IX, 440 pp.

IBBETSOn, David (1999): A Historical Introduction to the Law of Obligations (Oxford, Oxford University Press) 307 pp.

LAWSON, Frederick (1953): A Common Lawyer looks at the Civil Law (Ann Arbor, University of Michigan Law School) 238 pp.

LAWSON, Frederick (1997): "Further Reflections on Codification", en: LAWSON, Frederick, The Comparison - Selected Essays (Amsterdam, North Holland) vol. II, pp. 90-101.

LAWSON, Frederick y MARKESINIS, Basil (1982): Tortious Liability for Unintentional Harm in the Common Law and the Civil Law (Cambridge, Cambridge University Press) vol. I, 239 pp.

LESTER, Anthony (2000): "Human Rights and the British Constitution", en: Jowell, Jeffrey y Oliver, Dawn (edits.), The Changing Constitution (Oxford, Oxford University Press) $4^{\text {a }}$ ed., pp. 89-110.

MACCORMICK, Neil y Summers, Robert (1997): “Introduction”, en: MACCORMICK, Neil y Summers, Robert (edits.), Interpreting Precedents: A Comparative Study (Aldershot, Dartmouth Publishing) pp. 1-15.

MCKendricK, Ewan (2007): Contract Law (London, Palgrave Macmillan, 7a ed.) 473 pp.

MACKENZIE StUART, Alexander y WARnER, Jean Pierre (1981): "Judicial Decision as a Source of Community Law", en: GREWE, Wilhelm, RupP, H. y SCHNEIDER, H. (edits.) Europaische Gerichtsbarkeit und Nationale Verfassungsgerichtsbarkeit (BadenBaden, Nomos) pp. 273-781.

NichOLAS, Barry (1989): "The Pre-contractual Obligation to Disclose Information, English Report”, en: TAllon, Denis y Harris, Donald (edits.), Contract Law Today: Anglo-French Comparisons (Oxford, Clarendon Press) pp. 166-193.

POLLOCK, Frederick y MAITlAnD, Frederic (1968): The History of English Law (Cambridge, Cambridge University Press) 2a ed., vol. I, 688 pp.

SiMPSON, Alfred (1975): "Innovation in Nineteenth Century Contract Law", Law Quarterly Review, vol. 91, pp. 247-278.

Stapleton, Jane (1991): "Duty of Care and Economic Loss - A Wider Agenda”, Law Quarterly Review, vol. 107: pp. 249-297.

STEVEnS, Robert (2004): “The Contracts (Rights of Third Parties) Act 1999", Law Quarterly Review, vol. 120: pp. 292-323.

Treitel, Guenter (2003): The Law of Contract (London, Sweet \& Maxwell) 11 a ed., $1.117 \mathrm{pp}$. 
Treitel, Guenter (1989): “Consideration", en: GUEST, Anthony (edit.), Chitty on Contracts (London, Sweet \& Maxwell) 26a ed., vol. I, pp. 105-268.

TUNC, André (1986): "It is wise not to take codes too seriously", en: WALLingTON, Peter y MERKin, Robert (edits.), Essays in Memory of F.H. Lawson (London, Butterworths) cap. 7, pp. 71-85.

WADE, William y FORSYTH, Christopher (2004): Administrative Law (Oxford, Oxford University Press) 9a ed., 1030 pp.

WhitTaker, Simon (2001): "Public and Private Law-Making: Subordinate Legislation, Contracts and the Status of 'Student Rules', Oxford Journal of Legal Studies, vol. 21: pp. 103-128.

WhitTaker, Simon (2004): "Introductory", en: BeAle, Hugh (edit.), Chitty on Contracts (London, Sweet \& Maxwell) 29a ed., vol. I, cap. 1, pp. 3-118.

WhitTAKeR, Simon (2005): Liability for Products: English Law, French law and European Harmonization (Oxford, Oxford University Press) 687 pp.

WhitTAKer, Simon y Zimmermann, Reinhard (2000): "Good Faith in European Contract Law: Surveying the Legal Landscape", en: Zimmermann, Reinhard y WhitTAKer, Simon (edits.), Good Faith in European Contract Law (Cambridge, Cambridge University Press) pp. 7-62.

Zweigert, Konrad y KÖTZ, Hein (1987): An Introduction to Comparative Law (Traducc. Tony WeIR, Oxford, Oxford University Press) 2a ed., vol. II, 398 pp.

\section{NORMAS CITADAS}

\section{NORMAS DE LA UE}

Tratado constitutivo de la Comunidad Europea (Tratado de Roma, 25 marzo 1957) (Versión consolidada: Diario Oficial UE C (comunicaciones) $\mathrm{N}^{\circ} 325,24$ diciembre 2002).

Convenio Europeo sobre Derechos Humanos y Libertades Fundamentales, 4 noviembre 1950.

Directiva 73/148/CEE del Consejo, de 21 de mayo de 1973, relativa a la supresión de las restricciones al desplazamiento y a la estancia, dentro de la Comunidad, de los nacionales de los Estados Miembros en materia de establecimiento y de prestación de servicios. Diario Oficial UE L (Legislación) $\mathrm{N}^{\circ} 172,28$ junio 1973, p. 14.

Directiva 85/374/CEE del Consejo, de 25 de julio de 1985, relativa a la aproximación de las disposiciones legales, reglamentarias y administrativas de los Estados Miembros en materia de responsabilidad por los daños causados por productos defectuosos. Diario Oficial UE L N²10, 7 de agosto 1985, p. 29. Modificada por Directiva 1999/34/CE del Parlamento Europeo y del Consejo, de 10 de mayo de 1999. Diario Oficial UE L N 141, 4 junio 1999, p. 20.

Directiva 91/308/CEE del Consejo, de 10 de junio de 1991, relativa a la prevención de la utilización del sistema financiero para el blanqueo de capitales. Diario Oficial UE L N ${ }^{\circ}$ 166, 28 junio 1991, p. 77. Modificada por Directiva 2001/97/CE del Parlamento Europeo y del Consejo, de 4 de diciembre de 2001. Diario Oficial UE L N ${ }^{\circ}$ 344, 28 diciembre 2001, p. 76. 
Directiva 93/13/CEE del Consejo, de 5 de abril de 1993, sobre las cláusulas abusivas en los contratos celebrados con consumidores. Diario Oficial UE L N 95, 21 abril 1993, p. 29.

Directiva 97/81/CE del Consejo de 15 de diciembre de 1997 relativa al Acuerdo marco sobre el trabajo a tiempo parcial concluido por la UNICE, el CEEP y la CES Anexo: Acuerdo marco sobre el trabajo a tiempo parcial. Diario Oficial UE L N ${ }^{\circ} 14$, 20 enero 1998 , p. 9.

\section{NORMAS DEL REINO UNIDO}

Ley sobre Comité Judicial, 14 agosto 1833.

Ley sobre Judicatura de la Corte Suprema, 1873.

Ley sobre Jurisdicción de Apelación, 11 agosto 1876.

Ley sobre Corte de Apelaciones en lo Penal, 1907.

Ley sobre Responsabilidad de los Ocupantes, 6 junio 1957.

Ley sobre Arrendamiento con Opción de Compra, 16 julio 1964.

Ley sobre Falsa Representación, 22 marzo 1967.

Ley sobre Locales Defectuosos, 29 junio 1972.

Ley sobre Comunidades Europeas, 17 octubre 1972.

Ley sobre Consumidores de Crédito, 31 julio 1974.

Ley sobre Cláusulas Contractuales Abusivas, 26 octubre 1977.

Ley sobre Protección del Consumidor, 15 mayo 1987.

Ley sobre Gobierno de Gales, 31 julio 1998.

Ley sobre Escocia, 19 noviembre 1998.

Ley sobre Irlanda del Norte, 19 noviembre 1998.

Ley sobre Derechos Humanos, 30 noviembre 1998.

Ley sobre Contratos (Derechos de los Terceros), 11 noviembre 1999.

Ley sobre Reforma Constitucional, 24 marzo 2005.

\section{JURISPRUDENCIA CITADA}

A v. National Blood Authority (2001) 3 All ER 289.

Adams v. Lindsell (1818) 1 B. \& Ald. 681.

A.-G. v. Blake (2001) 1 AC 268.

Anns v. Merton LBC (1978) AC 728.

Arthur JS Hall \& Co v. Simons (2002) 1 AC 651.

Associated Picture Houses Ltd. v. Wednesbury Corpn. (1948) 1 KB 223.

Autologic Holdings plc v. IRC (2005) UKHL 54 (2006); 1 AC 118.

Barclays Bank plc v. O’Brien (1994) 1 AC 180.

Bell v. Lever Bros (1932) AC 161.

Bowman v. Fels (2005) EWCA Civ 226 (2005); 4 A11 ER 609.

C v. DPP (1996) AC 1.

Cambridge Water Co. v. Eastern Counties Leather plc (1994) 2 AC 264, pp. 297-300.

Caparo Industries plc v. Dickman (1990) 2 AC 605.

Cavalier v. Pope (1906) AC 428. 
Central London Property Trust Ltd. v. High Trees House Ltd. (1947) KB 130.

Countryside Alliance and others v. A.-G. (2005) EWHC 1677 (Admin).

Cundy v. Lindsay (1878) 3 App.Cas 459 HL(E).

D v. East Berkshire Community NHS Trust (2004) QB 558; (2005) UKHL 23; (2005) 2 AC 373 (Cámara de los Lores).

D \& C Builders v. Rees (1965) 3 All ER 837.

Davis Contractors Ltd. v. Fareham UDC (1956) AC 696.

Director General of Fair Trading v. First National Bank (2001) UKHL 52; (2002) 1 AC 481.

Donoghue v. Stevenson (1932) AC 562.

Dunlop Pneumatic Tyre Co. Ltd. v. Selfridge \& Co Ltd. (1915) AC 847.

Farrell v. Alexander (1977) AC 59.

Felthouse v. Bindley (1862) 11 CBNS 869.

Foakes v. Beer (1884) 9 App.Cas. 605.

Freiburger Kommunalbauten GmbH Baugesellschaft \& Co KG v. Hofstetter, Caso C-237I

02 de 1 de Abril de 2004.

Goodwin v. United Kingdom (2002) 35 EHRR 18.

Gough v. Chief Constable (2002) EWCA Civ 351; (2002) 2 All ER 985.

Great Peace Shipping Ltd. v. Tsavliris Salvage (International) Ltd. (2002) EWCA Civ 1407 (2003); QB 679.

Gribbon v. Lutton (2001) EWCA Civ. 81.

Harbutt's 'Plasticine' Ltd. v. Wayne Tank and Pump Co. Ltd. (1970) 1 QB 447.

Hart v. O'Connor (1985) AC 1000 Privy Council.

Hedley Byrne \& Co. Ltd. v. Heller \& Partners Ltd. (1964) AC 465.

Henderson v. Merrett Syndicates Ltd. (1995) 2 AC 145.

Hodgson v. Marks (1971) Ch. 89.

Hollier v. Rambler Motors Ltd. (1972) 2 QB 71.

Huddersfield Police Authority v. Watson (1947) KB 842.

Hyde v. Wrench (1840) 3 Beav. 334.

Ingram v. Little (1961) 1 QB 31.

Interfoto Picture Library Ltd. v. Stiletto Visual Programmes Ltd. (1989) QB 433.

Invercargill City Council v. Hamlin (1996) AC 624.

Investors Compensation Scheme Ltd. v. West Bromwich Building Society (1998) 1 WLR 896.

Jones v. National Coal Board (1957) 2 WLR 760, p. 766 Denning LJ.

Kleinwort Benson Ltd. v. Lincoln City Council (1999) 2 AC 349.

Köbler v. Austria Caso C-224/01 (2003) I-10239.

Leeds City Council v. Price (2006) UKHL 10.

L'Estrange v. F. Graucob Ltd. (1934) 2 KB 394.

Lewis v. Averay (1972) 1 QB 198.

Lipkin Gorman v. Karpnale Ltd. (1991) 2 AC 548.

London Borough of Newham v. Khatun (2004) EWCA Civ 55 (2005); QB 37.

Llonrho plc v. Fahed (No 4) (1994) 1 All ER 870 (High Court y la Corte Suprema de

Australia). 
Mathews v. Kent and Medway Towns Fire Authority (2006) UKHL 6; (2006) 2 All ER 171.

Murphy v. Brentwood District Council (1991) 1 AC 398.

O’Byrne v. Sanofi Pasteur SA, Caso C-127/04 de 9 de Febrero de 2006.

Pao On v. Lau Liu Long (1980) AC 614 Privy Council en.

Phillips v. Brooks Ltd. (1919) 2 KB 243.

Photo Production Ltd. v. Securicor Transport Ltd. (1980) AC 827.

$R v$. Blastland (1986) AC 41.

R. v. Clarence (1888) 22 QBD 23.

$R v$. North and East Devon Health Authority Ex p. Coughlan (2001) QB 213.

$R v . R$ (1992) 1 AC 599.

R. v. Secretary of State for Transport Ex p. Factortame Ltd. (No. 2) (1991) 1 AC 603.

$R$ (Alconbury Developments Ltd.) v. Secretary of State for the Environment, Transport and the Regions (2001) UKHL 23 (2003); 2 AC 295.

$R$ (Ullah) v. Special Adjudicator (2004) UKHL 26; 2 AC 323.

Ratten (1971) 3 All ER 801.

Re Selectmove Ltd. (1995) 1 WLR 474.

Rimmer v. Liverpool City Council (1985) QB 1.

Rondel v. Worsley (1969) AC 191.

Royal Bank of Scotland v. Etridge (No 2) (2001) UKHL 44 (2002); 2 AC 773.

Royal Bank of Scotland v. Etridge (No 2) (2001) UKHL 14 (2002); 1 WLR 1397.

Royscott Trust Ltd. v. Rogerson (1991) 2 QB 297.

Rylands v. Fletcher (1865-1866) LR 1 Ex. 265, p. 279; (1868) LR 3 HL 330 (Cámara de los Lores).

Secretary of State for Work and Pensions v. M (2006) UKHL 11.

Shogun Finance Ltd. v. Hudson (2003) UKHL 62 (2004); 1 AC 919.

Simon Container Machinery Ltd. v. Emba Machinery A.B (1998) 2 Lloyd's Rep. 429.

Solle v. Butcher (1950) 1 KB 671.

South Caribbean Trading Ltd. v. Trafigura Beheer BV (2004) EWHC 2676 (2005); 1 Lloyd's Rep. 128.

Spring v. Guardian Assurance Plc. (1995) 2 AC 296.

Stilk v. Myrick (1809) 2 Camp. 317.

Suisse Atlantique Société d'Armement Maritime SA v. N.V. Rotterdamsche Kolen Centrale (1967) 1 AC 361.

Tai Hing Cotton Mill Ltd. v. Liu Chong Hing Bank Ltd. (1986) AC 80.

The Case of Proclamations (1610) 12 Co Rep 74, p. 76.

Thornton v. Shoe Lane Parking Ltd. (1971) 2 QB 163.

Transco plc v. Stockport MBC (2003) UKHL 61, (2004) 2 AC 1.

Tweddle v. Atkinson (1861) 1 B \& S 393.

Veedfald v. Arhus Amtskommune, Caso C-203/99 (2001), ECR 1-3569.

Williams v. Roffey Bros \& Nicholls (Contractors) Ltd. (1991) 1 QB 1.

Woodar Investment Development Ltd. v. Wimpey Construction Ltd. (1980) 1 WLR 277.

X (Minors) v. Bedfordshire County Council (1995) 2 AC 633. 
Yaxley v. Gotts (2000) Ch. 162.

Young v. Bristol Aeroplane Co. Ltd. (1946) AC 163.

\section{ABREVIATURAS UTILIZADAS}

AC $=$ Law Reports, Appeal Cases (Third Series).

All ER = All England Law Reports.

App Cass = Law Reports, Appeal Cases (Second Series).

B. \& Ald. = Barnewall \& Alderson's King's Bench Reports.

B \& $S=$ Best \& Smith's Queen's Bench Reports.

Beav $=$ Beavan's Rolls Court Reports.

Camp = Campbell's Nisi Prius Cases

CBNS $=$ Common Bench Reports, New Series.

$\mathrm{CE}=$ Comunidad Europea.

$\mathrm{CEE}=$ Comunidad Económica Europea.

$\mathrm{CEEP}=$ Centro Europeo de Empresas con Participación Pública.

CES = Consejo Económico y Social.

$\mathrm{Ch}=$ Law Reports, Chancery Division.

Co Rep $=$ Coke's King's Bench Reports.

$\mathrm{ECR}=$ European Court Reports.

EHRR = European Human Rights Reports.

EWCA / EWCA Civ. = Court of Appeal (Civil Division).

EWHC $=$ England $\&$ Wales High Court (Administrative Court) (Neutral Citation).

$\mathrm{Ex}=$ Exchequer Reports.

HL/HLC = Clark \& Finnelly's House of Lords Reports New Series.

$\mathbf{J}=$ juez de la High Court.

KB = Law Reports, King's Bench.

$\mathrm{LJ}=$ ("Lord Justice") $=$ juez de la Corte de Apelaciones.

Lord = juez de la Cámara de los Lores.

Lloyd's Rep. = Lloyd's List Law Reports.

LR = Law Reports.

QB / QBD = Law Reports, Queen's Bench (Division).

TEDH $=$ Tribunal Europeo de Derechos Humanos.

TJCE = Tribunal de Justicia de las Comunidades Europeas.

$\mathrm{UE}=$ Unión Europea.

UKHL $=$ United Kingdom House of Lords.

UNICE = Unión de Confederaciones de la Industria y de los Empleadores de Europa.

WLR = Weekly Law Reports. 
